\title{
BUYER'S WILLINGNESS TO PAY FOR DWELLINGS WITH DIFFERENT ORIENTATIONS
}

\author{
Han-Suck SONG ${ }^{1}$, Mats WILHELMSSON ${ }^{1}$, Mo ZHENG $^{1 *}$ \\ ${ }^{1}$ Division of Building and Real Estate Economics, Department of Real Estate and Construction Management, \\ KTH - Royal Institute of Technology, Teknikringen 10B, $5^{\text {th }}$ floor, 10044 Stockholm, Sweden
}

Received 30 January 2019; accepted 22 May 2019

\begin{abstract}
This paper applies spatial hedonic econometric models to estimate the willingness of buyers to pay for dwellings with different orientations based on a data set comprising 63306 transactions of secondhand apartment sales in 10 districts in Beijing from October 2011 to September 2014. Our results indicate that apartments with South orientation are sold at a 7.8\% premium compared with those with West orientation, and that apartments in ancient city areas are more sensitive to orientation. The obtained results can help architects and developers to maximize the value of development projects by optimizing the layout of apartment units on each floor.
\end{abstract}

Keywords: residential market, Beijing, spatial Durbin model, orientations, hedonic regression.

\section{Introduction}

The orientation and facing direction of buildings have historically played a critical role in Chinese culture. For instance, when the inner city of Beijing was redesigned during the Ming Dynasty, it was built in a rectangular shape with its axis of symmetry traveling in the northsouth direction (Meyer, 1978).

As for the architectural history of Beijing, the most famous and traditional type of residence is the courtyard house (siheyuan), which consists of a courtyard surrounded by walls or buildings on all four sides. It is a standard courtyard house, typically oriented in the southnorth direction and the master bedroom and the living room should face south because this direction makes good use of sunlight. East and West wing rooms are used for guests and children's residence. Indeed, this type of design dominated the entire housing market for over 600 years in Beijing, from the Ming Dynasty to the Qing Dynasty (1644-1911) (Xu, 1998).

Furthermore, the allocations of which individual or individuals ought to live in certain rooms with different directions (e.g., family members, guests, servants) reflect social hierarchies (Lu \& Jones, 2000). And south direction is the most respectable orientation in ancient Chinese society (Guo \& Guo, 2001).

In fact, this type of architectural design could also be explained by the climate in Beijing. Geographically, Bei- jing is located in the northeast of China with prevailing winds come from the southeast direction in the summer, and suffers a northwest wind during winter. Thus, dwellings must be designed to protect the household against the northwest wind. During summer, humid southeast wind is preferred to satisfy the need of ventilation. In addition, the structure of a house is ideal if it meets the needs for maximum winter sun radiation and gentle summer sun shading. Consequently, the orientations of apartments in Beijing are related to individual households' need for comfort due to climate conditions. Moreover, the orientations may be related to household economy. For instance, sufficient sunlight, from a south-facing orientation can have a positive influence on the housework efficiency when drying the clothes in the balcony.

Nowadays, newly built apartment buildings in Beijing are often medium to high-rise and locates away from city center. And for secondhand market and apartment in central areas are mainly low-rise 6 storey buildings, and constrained by old urban planning, most of the apartments have limited or no access to green space and view, which makes directions and facing more important to achieve a higher standard of living. The main objective of this paper is to study the willingness of individuals to pay for dwellings with different orientations in Beijing. Thus determining whether there are preferences of buyers to buy

*Corresponding author. E-mails: mo.zheng@abe.kth.se 
apartments with certain orientations is an interesting area of research in light of the fact that Beijing (as well as other metropolitan areas in China) has undergone several decades of rapid modernization and urbanization.

Based on about 63306 transactions of secondhand apartments in 10 districts in Beijing from October 2011 to September 2014, we estimate the determinants of transaction prices focusing on apartment orientations. Using both traditional hedonic ordinary least squares (OLS) models and spatial econometric models, we find that apartments with south orientation are sold at a $7.8 \%$ premium compared with west-oriented apartments. Furthermore, apartments located in ancient city areas are more sensitive to orientation than other areas. This study can help architects and developers to maximize the value of development projects by optimizing the layout of apartment units on each floor.

The remaining sections of this paper are organized as follows: In the subsequent section, the fundamental, historical, and theoretical frameworks of hedonic regression in both Northern Hemisphere and Southern Hemisphere markets are illustrated. Next, the construction of the OLS and econometric models applied in this paper, with a particular focus on the Spatial Durbin Model (SDM), is presented, and followed by a description of the data. The statistical regression and test results are then presented. In the final two sections, the results are discussed and conclusions are drawn.

\section{Literature review}

Hedonic price modelling (HPM) is a very popular method to study and learn about how prices for certain goods are determined by the aggregated value of a set of attributes or characteristics (Griliches, 1958; Rosen, 1974). Although Griliches (1961) considers Court (1939) research on hedonic price indexes with automotive examples as the first application of HPM, Colwell and Dilmore (1999) believe that both Haas (1922) and Wallace (1926) analysis of farm land appraisals, constitute two of the earliest and high impact hedonic studies. Haas (1922) estimated hedonic regression models for farmland in Minnesota (US) with distance to city center, and the city size, as two important explanatory variables. Wallace (1926) and Waugh (1929) applied similar HPM to study the relationship between price of farmland and price of vegetables.

Lancaster (1966) and Rosen (1974) seminal works were first to develop the microeconomic theoretical foundations of HPM. Lancaster (1966) developed models for consumption theory that stated that it is the demand for products are based on their characteristics, not the good themselves. Rosen (1974) developed an equilibrium model for product differentiation based on the hedonic hypothesis that goods are valued for their characteristics or utilitybearing attributes.

Multiple regression analysis is the main statistical method in empirical HPM, and already early economet- ric papers on determinants of house prices divided various value-contributing characteristics into different main categories. This is made possible thanks to access to the many free-market transactions of homes where the transaction prices reflect the market values determined through a bundle of characteristics. Ridker and Henning (1967), and Oates (1969) are examples of early research that applied HPM to real estate research. Kain and Quigley (1970) empirically estimated the value of housing quality and found that housing value reflects a complex mixture of quantitative characteristics of a dwelling itself (e.g. number of rooms, number or bathroom, and lot size), with a bundle of qualitative characteristics of both dwelling units, structure, parcel and other neighborhood characteristics.

It is thus common practice in housing market hedonic regression modelling to divide price determining housing attributes into a number of main attribute classes such as: dwelling and building structure attributes (e.g. number of rooms, unit size, lot size, access to swimming pool and air condition, balcony, and elevator), neighborhood community attributes (e.g. closeness to high-quality schools, various socio-economic conditions such as level of crime, noise from e.g. aircraft and other transportation infrastructure, proximity to transportation services, and nature), locational attributes (e.g. proximity to CBD and downtown areas, shopping malls, and transportation services). Due to the popularity of housing hedonic regression models, there exist several literature sources with broad reviews of hedonic studies of housing markets (for recent reviews, see e.g. Ottensmann, Payton, \& Man, 2008; Xiao, 2017; Metzner \& Kindt, 2018).

A large number of researchers focus on the Asian property markets and the determinants of apartment prices. Commonly included variables are for example school quality (Black, 1999), environmental quality (Harrison \& Rubinfeld, 1978; Nelson, 2008), safety (Clark \& Cosgrove, 1990), and accessibility (Andersson, Shyr, \& Fu, 2010).

It is commonly believed that property seekers are willing to pay more for scenic views, and a number of research papers address this topic. Benson, Hansen, Schwartz, and Smersh in 1998 took "view" into their hedonic model. In theirs paper, they divided "view" into "oceanfront, ocean view, partial ocean view and no view" and stated that the property locates at oceanfront has $147 \%$ more value than properties with no view, followed by ocean view by $32 \%$, and partial ocean view by $10 \%$. Similarly, Chin, Chau, and $\mathrm{Ng}$ (2004) find that cemetery views have a negative impact on property prices, whereas properties with sea views are sold at a premium in Malaysia. Other studies find that the presence of sanitary landfills decreases housing prices and is associated with the potential for bringing bad luck to nearby residents (Hite, Chern, Hitzhusen, \& Randall, 2001). Wen, $\mathrm{Bu}$, and Qin (2014) studies the spatial effect of lake landscape on properties prices, and the research area is the West Lake, Hangzhou, China. No spatial models or Moran's I are tested, instead, they apply a standard hedonic regression with 6 different directions and distance 
integrated dummy variables to control for spatial heteroscedasticity problem. Their research concludes that the apartments that have direct access or view over the West Lake are most expensive, and the absolute value of the distance elasticity coefficient decreases.

A study of housing preferences in Beijing uses questionnaire with four explanatory attribute, one of them is orientation which are defined as "south", "north", "east" and "west". The result shows that orientation will affect the buyers' choices. The reason behind is that south direction properties have better sunlight penetration and ventilation. Another explanation is that south direction is mostly preferred according to Feng Shui theories (Wang $\& \mathrm{Li}, 2004)$. Later on, Wang and Li operated the same experiments in Guangzhou, located in south China in 2006, and came out a similar result. The result is in line with the previous one for Beijing, south oriented dwellings are most favored and west ones ranked least with a unit price discount about $2789 \mathrm{RMB} / \mathrm{m}^{2}$. What's more, they also realize that high-income group shows more concern for westfacing units (Wang \& Li, 2006).

The interviews conducted in Juer hutong which is located in inner Beijing city about the satisfaction of their dwellings illustrated that, residents are satisfied about the south-facing balconies which provide the room with abundant sunshine, and prevent cold west wind during winter. Apartments that are with east and west directions are not as preferable, as hot air during summer and cold air during winter comes from the west-facing windows (Zhang, 2016). Bouillot (2008) studied the impact of climate in architectural designs of vernacular housing in different provinces in China and stated that, houses with orientations that are suitable for the local climate and seasonal bioclimatic conditions are preferred.

Gao and Asami applied hedonic regression in 2011 to analyze the detriment variable of the apartment prices in Beijing and concluded that direction is one of the key variable, the unit price of a south-north oriented apartment is about $800 \mathrm{RMB} / \mathrm{m}^{2}$ higher than those with east and west direction (Gao \& Asami, 2011). But in thesis study, there are only 300 observations which are transacted in 12 weeks in May 2006. The drawback of this study is that sample size is too small and constrained. Lu (2018) used 2996 observations to analyze the value of a south orientation on apartment prices in Shanghai, and found a $14 \%$ premium for apartments that are south-oriented. Fadaei, Iulo, and Yoshida (2015) studied the impact of orientation and elongation for 8164 single family detached houses on housing prices in central Pennsylvania, they concluded that the choice of orientation has a significant impact on housing prices and energy consumption; North-south orientation with the long side facing south and north are desired and has a positive impact on property prices.

Many empirical researches have studied the importance of socio-cultural related attributes in purchase making decisions. For instance, the Feng Shui system in Asian societies as stated in Sidi's study in 2010 (Sidi, 2010). Feng shui, which literally translates as "wind" and "water" in English is commonly known as ancient Chinese geomancy. The main concept is to arrange your life to be associated with Qi, which is considered as the fundamental elements for energy that affects health, peace, fortune, etc. (Xu, 1998). Many households in Asian countries would prefer houses with good Qi arrangement. Generally, the residential building should be placed for the right direction and longer side of the buildings should face south in Northern Hemisphere (Thongkamsamut \& Buranakarn, 2007). Similar suggestions could also be found in $\mathrm{Xu}$ (1997), Kim (2006) and Tan (2012).

Traditionally, the Chinese traditional architecture theory is a combination of Fengshui, psychology and environmental sustainability (Liu, 1996). Houses that are built following a South-north axis are most common and preferred; the preference is inseparable from China's geographical location. South orientated rooms are servicing as the living room and bedrooms, while north orientated rooms are used for storage (Liu, 1996; Zhang, 2006; Xu, 2009; Li, 2016). Furthermore, south-north apartments can enjoy sufficient but not glaring sunshine, have good ventilation, and save energy (Guo \& Wang, 2008). Considering the actual climate situation and being influenced by traditional concepts, in the northern part of China, most of the apartments are South-North oriented (Meng, 1985).

Due to many constraints, such as economical, plot sizes, zoning and other types of regulations, apartments are built with other orientations as well. Relative to the Southnorth apartments, the most mentioned is the East-west ones. Comparing with south-north apartments, there are several significant disadvantages for apartments that are east-west oriented: excessive sunlight (Jin, 1981), bad ventilation (Zeng \& Ping, 2007), excessive energy consumption especially for heating, and bad insulation (Zhang, 1990; Guo \& Wang, 2008).

Furthermore, several researchers also discuss the shortcomings of apartments with other orientations, such as pure west and pure north oriented apartment. The discussion of avoiding west-oriented bedrooms and westoriented apartments could be traced back to the 1960 s by Liu (1964). Liu mentioned that, west-oriented apartment should be avoided when planning roads and complexes in the residential areas of China; even if it subjected to structural constrains, the peripheral material should be specialized. Moreover, try to plant green belts and taller trees in front of the west side of the building to avoid direct sunlight. Liu, Ren, and Lian (2018) analyzed the indoor thermal environment of residential building in $\mathrm{Da}$ lian, they concluded that, West-oriented apartments have the highest indoor temperature in the summer and lowest temperature in the winter, ranging from $13.8 \sim 25.5^{\circ} \mathrm{C}$ while North-oriented apartments have a difference from 19.2 23.7 (result from 24 hours indoor temperature monitor) in the winter.

According to Li and Jiang (2006)'s research on household utility consumptions, air conditioner cost composites 
two third of the household utility bills during summer. Most of the households have equipped two air conditioners; however, north-oriented rooms are generally not equipped. Therefore, this means, electricity cost various substantially for households that live in different orientations. Comparing with household that live in northoriented apartment, people who live in the west-oriented apartment has to pay a much higher electricity bill during summer. Yet another influencing factor are the ultraviolet rays from strong sunlight, which result in fading and accelerated aging of furniture and articles in the west-oriented rooms (Wei, 2007).

In order to increase the attractiveness of apartments with less attractive orientations, researchers discuss solutions mainly with construction and material selection phases, such as increasing productivity and quality of construction team, select a better insulation material (see Jin, 1981; Zhang, 1990; Liu, 1996; Guo \& Wang, 2008; Weng, 2008). Sui, Wang, and He (2014) proposed that bay window design and window size should be considered in the west-oriented rooms to reduce the influence of dazzle and overheating caused by direct afternoon west sun.

The studies of directions are not only conducted in Northern Hemisphere. Mak and Ng (2005) did an empirical survey with architects in both Hong Kong and Sydney, and the results shows that in Sydney, given the differences in northern and southern hemispheres, the selection of layout of buildings concurs with the ideal Feng Shui principles, where north directions designs are more preferred. Many of the papers that focus on Southern Hemisphere analyze the impact of orientation on energy saving and sunlight. Ren, Foliente, Chan, Chen, and Syme (2011) did the research on the carbon emissions in the residential houses and presented a new tool to design houses with low and zero emission houses in Australia. They mentioned that the houses are usually orientated to be northfacing in order to gain solar heat during winter. Andersen, Cook, and Marceau (2004) studied the solar energy system in Sydney Olympic village and proposed that exposing north-facing windows for winter sun is a possible method for developers to increase energy efficiency.

\section{Methodology}

Both OLS models and spatial econometric models are estimated to obtain the impact of attributes on price per square meter (PSM). For a review of hedonic models, see Follain and Jimenez (1985), Sheppard (1999), and Malpezzi (2003).

We apply Malpezzi's (2003) framework to divide hedonic attributes into three main categories:

- Structural attributes (e.g., size, number of rooms, type of rooms, age).

- Locational attributes (e.g., distance to central business district [CBD], distance to nearest bus stop).

- Neighborhood attributes (e.g., proximity to public schools, crime rate, level of noise, population density).
Because our main focus is estimating the value of different orientations, we add a fourth main category: orientation attributes. These attributes are dummy variables that describe the orientation of rooms in an apartment, as outlined in the following paragraphs.

Geographic information system (GIS) techniques are used to compute spatial attributes, such as distance to different types of amenities, and to obtain latitude and longitude data. Ignoring the spatial relationship could result in biased and inefficient OLS parameter estimations and errors in the statistical diagnostic interpretations (Anselin, 1988).

There exist a number of spatial autoregressive models that are of interest to housing and urban studies. These include spatial autoregressive lag (SARlag) models (the spatial dependence is present in the dependent variable); spatial autoregressive error (SARerr) models (the autocorrelation appears in the error term); and the SDM (with dependence in the error terms in cross-sectional data and includes spatial lags in both the independent variable and the explanatory variables) (see, e.g., Osland, 2010; LeSage, 2015).

The structural equation of the SDM can be written as follows:

$$
\begin{aligned}
& y=\alpha \mathrm{l}_{N}+\rho W y+X \beta+W X \gamma+\varepsilon, \\
& \varepsilon \rightarrow \text { i.i.d }\left(0, \sigma^{2} \mathrm{I}_{N}\right) .
\end{aligned}
$$

where: $y$ represents a vector of the $N \times 1$ dependent variable and $X$ is a matrix of the independent variables. Here we apply Malpezzi's attributes matrix plus orientation attributes, so $X$ is equal to structural, locational, neighborhood, and orientation attributes, and $\beta$ is the coefficient that indicates the implicit price of the explanatory variable; $W$ is an $N \times N$ spatial weights matrix; $\gamma$ is a parameter of lag on $W X$, and $\rho$ is the coefficient of a spatially lagged dependent variable. This model was developed to overcome the dependencies problem in spatial regressions in both dependent variables and independent variables. The SDM could be simplified as a SARlag model if $\gamma=0$ holds and as a spatial error model if $\gamma=-\rho \beta$. The maximum likelihood estimation (MLE) will be used in all spatial models.

One of the greatest advantages of applying the SDM is the ability to separate the impact and significance of the direct and indirect (or spillover) effects. For observation $i$ and $r^{\text {th }}$ variable, $\partial y_{i} / \partial x_{i r}$ captures the combination impacts of both direct and indirect (which is feedback effect form neighborhood influences) for changes in $x_{i r}$ on dependent variable $y_{i}$. The direct effect is often used to test the hypothesis of whether a particular variable has a significant impact on a dependent variable in its own economy rather than the estimated coefficient. Lesage and Pace proposed to label direct effects to express the impact of the changes of explanatory variables on its own dependent variable. As for the indirect effect, it is applied to test that the spatial spillover exists and measures the impact of changes of explanatory variable $x_{i r}$ on dependent variable for all other units $y_{j}$, which is the spillover impact of $r^{\text {th }}$ variable on the neighboring regions (LeSage \& Pace, 2010). 


\section{The data}

In this paper, we use all arm's-length actual transaction records, which are considered to be more objective than advertised prices. The dataset used in this article was collected from an online real estate platform Lianjia (also known as Homelink) which opens to public. Beside brokerage, Lianjia is also a real estate database company and has its own industrial analysis research institution. According to the Beijing Municipal Commission of Housing and Urban-Rural Development's official records, Beijing Lianjia Real Estate Agency ranks top among agencies in terms of transaction volumes and occupies over $50 \%$ of the market share. The total price, PSM, number of bedrooms, size_category, age, location within a school zone, classification as a tax benefit unit, transaction date, type of property, orientation, and level of decor are some of the important pieces of public information recorded by certified marketing agents.

Based on Tobler's (1970) first law of geography, which states that "everything is related to everything else, but near things are more related than distant things", we expect a certain degree of spatial autocorrelation in all models. To examine the relationship between apartment prices and spatial attributes, we apply GIS and global positioning systems (GPS) to add spatial factors. With support from ArcGis and Google Maps, we construct three types of variables:

1. The latitude and longitude of the individual property are recorded in the Word Geodetic System 1984 (WGS84).

2. The distance to location $i$ (metro station, city center, park, river, pond, exits) is calculated to the nearest meter.

3. Dummy variables within distance $n$ (meters such as $100 \mathrm{~m}, 500 \mathrm{~m}$ ) to location $i$ are created.

A large number of data are required to practice the hedonic approach. This paper uses a unique data set consisting of 63306 transactions through Lianjia of secondhand apartment sales in 10 districts in Beijing from October 2011 to October 2014. In total, 72 variables are selected, which comprehensively comprises structural, neighborhood, and locational attributes, as well as orientation attributes. Table 1 presents some descriptive statistics for the variables.

The geographical area under investigation in this study covers 161 subzones (Jiedao街道) in 10 districts encircled by the Sixth Ring Road, a land area of over $2300 \mathrm{~km}^{2}$ in Beijing. Because the districts of Fangshan, Mentougou, Minyun, Pinggu, Huairou, and Yanqing have no or limited records, we do not include these districts in this paper.

The Xicheng District is of special interest in this paper. The apartments have the highest mean prices (see Figure A2) of all the districts included in this study. Also, the residents working in Xicheng District have the highest salaries in Beijing according to eBeijing, the Official Website of the Beijing Government (2012). The Xicheng District has been serving as the political center for almost a thousand years. The Forbidden City, and most of the central government institutions, are located in this district. People who can trace their family heritage back for generations in this city are considered native Beijingese. Before the Communist takeover, most members of Chinese royalty and nobility had resided there for thousands of years (Di \& Xiao, 1987; Gu \& Ryan, 2008). Xicheng District is $32 \mathrm{~km}^{2}$ in area which is divided into 15 Jiedao-level sub-districts and, according to the 2000 national census, has a population of over 700000 people. Due to the special characteristics of the Xicheng District, we compare econometric results based on Xicheng District data with the econometric results based on the entire data set.

\subsection{Data description}

The logarithm of price per square meter is chosen as the dependent variable. The size related variables are classified into four categories based on the square meter sizes of the apartments. We also control for the age of a building and if individual apartments are decorated in a luxury style according to real estate agent's descriptions.

A building is either categorized as a high-rise building with elevator, or a low-rise building without elevator. We have created following four interaction dummy variables: variable lriselposi (= 1 if the apartment is located at lower level of a low-rise building); variable lrisehposi (= 1 if the apartment is located at higher level of a low-rise building; variable hriselposi (= 1 if the apartment is located at lower level of a high-rise building); and variable hrisehposi (= 1 if the apartment is located at higher level of a highrise building). We let the variable lriselposi be the default variable. Apartments that are located at higher levels (positions) in high- and low-rise buildings also have a higher probability of having a better view. These four interaction variables are key in the below econometric estimations and we estimate separate econometric models with four different sub-samples created from these four interaction dummies.

The variable schoolzone shows the level of home seekers' willingness to pay to live close to a primary school. Location matters when living in a city as huge as Beijing. Distances to various public facilities are key variables in terms of locational attributes. We believe that tobus100, the dummy variable that indicates whether a property is within 100 meters walking distance to the nearest bus stop, will have a significant positive impact on the property PSM; another key variable is the metro related variable, which indicates that whether a property is within a 400 meters walking distance from a nearest train station and whether the nearest metro station is the metro junction. Unlike most research papers that take the distance to airport variable into consideration, we instead use the distance to nearest highway or expressway exit variable because in Beijing, airport proximity would benefit only commercial units or business people mainly in Yishun District, where the airport is located (traffic time to airport is more important in this situation). To include the 
Table 1. Description of data on Beijing residential markets. The number of observations is 63306 for the entire study area

\begin{tabular}{|c|c|c|c|c|c|}
\hline Variable & Description & Mean & Std. Dev. & Min & Max \\
\hline \multicolumn{6}{|l|}{ Dependent variable } \\
\hline $\log (\mathrm{PSM})$ & Logarithm of Price per square meter (CNY) & 10.240 & 0.4115 & 8.335 & 13.548 \\
\hline \multicolumn{6}{|c|}{ Basic independent variables } \\
\hline age & Age of building (years) & 11.736 & 6.6368 & 1 & 62 \\
\hline $\operatorname{lux}$ & $=1$ if apartment has luxury decoration & 0.5507 & 0.4974 & 0 & 1 \\
\hline schoolzone & $=1$ if the property is located in a primary school zone & 0.3949 & 0.4888 & 0 & 1 \\
\hline taxfree & $=1$ if the property has tax benefits & 0.5235 & 0.4995 & 0 & 1 \\
\hline size_category & Size of the apartment in squared meters & & & & \\
\hline size_cat1 & Default: if size $<50$ & 0.1313 & 0.3378 & 0 & 1 \\
\hline size_cat2 & $=1$ if $50 \leq$ size $<90$ & 0.5666 & 0.4956 & 0 & 1 \\
\hline size_cat3 & $=1$ if $90 \leq$ size $<144$ & 0.2129 & 0.4094 & 0 & 1 \\
\hline size_cat 4 & $=1$ if $144 \leq$ size & 0.0892 & 0.2850 & 0 & 1 \\
\hline Floor and position & High-rise building. if total floor $>6$. with elevator & & & & \\
\hline lriselposi & $\begin{array}{l}\text { Default: if apartment is located in the bottom position of a } \\
\text { low-rise building }\end{array}$ & 0.3425 & 0.4745 & 0 & 1 \\
\hline lrisehposi & $\begin{array}{l}=1 \text { if apartment is located in the top position of a low-rise } \\
\text { building }\end{array}$ & 0.2391 & 0.4265 & 0 & 1 \\
\hline hriselposi & $\begin{array}{l}=1 \text { if apartment is located in the bottom position of a high- } \\
\text { rise building }\end{array}$ & 0.2761 & 0.4471 & 0 & 1 \\
\hline hrisehposi & $\begin{array}{l}=1 \text { if apartment is located in the bottom position of a high- } \\
\text { rise building }\end{array}$ & 0.1423 & 0.3494 & 0 & 1 \\
\hline \multicolumn{6}{|l|}{ Metro variables } \\
\hline transit0_metro0 & $\begin{array}{l}\text { Default: if distance to metro }>400 \mathrm{~m} \text {. and the nearest station } \\
\text { is not a transit station. }\end{array}$ & 0.7055 & 0.4558 & 0 & 1 \\
\hline transit1_metro0 & $\begin{array}{l}=1 \text { if distance to metro }>400 \mathrm{~m} \text {. but the nearest station is a } \\
\text { transit station. }\end{array}$ & 0.1781 & 0.3826 & 0 & 1 \\
\hline transit0_metro1 & $\begin{array}{l}=1 \text { if distance to metro }<400 \mathrm{~m} \text {. but the nearest station is not } \\
\text { a transit station. }\end{array}$ & 0.0822 & 0.2747 & 0 & 1 \\
\hline transit1_metro1 & $\begin{array}{l}=1 \text { if distance to metro }<400 \mathrm{~m} \text {. and the nearest station is a } \\
\text { transit station. }\end{array}$ & 0.0342 & 0.1817 & 0 & 1 \\
\hline dtexits $(\mathrm{m})$ & Distance to expressway or highway exit (meter) & 1283 & 1165 & 7 & 12572 \\
\hline toexits 100 & Within $100 \mathrm{~m}$ to nearest expressway or highway exit & 0.0137 & 0.1162 & 0 & 1 \\
\hline tobus 100 & Within $100 \mathrm{~m}$ to nearest bus stop & 0.2111 & 0.4081 & 0 & 1 \\
\hline \multicolumn{6}{|c|}{ Time and Location fixed effect dummy variables } \\
\hline Transaction Month & Time dummies: from 2011-10 to 2014-09 & & & 0 & 1 \\
\hline 201110 & Default: if the transaction is in Oct 2011 & & & & \\
\hline \multicolumn{6}{|l|}{$\ldots$} \\
\hline \multicolumn{6}{|l|}{201409} \\
\hline \multicolumn{6}{|l|}{ District dummy } \\
\hline Chaoyang & Default: if the apartment is located in Chaoyang & & & & \\
\hline Haidian & $=1$. Haidian district & 0.1376 & 0.3445 & 0 & 1 \\
\hline Xicheng & $=1$. Xicheng district & 0.0831 & 0.2760 & 0 & 1 \\
\hline Dongcheng & $=1$. Dongcheng district & 0.0384 & 0.1921 & 0 & 1 \\
\hline Daxing & $=1$. Daxing district & 0.0920 & 0.2891 & 0 & 1 \\
\hline Shunyi & $=1$. Shunyi district & 0.0562 & 0.2303 & 0 & 1 \\
\hline Fengtai & $=1$. Fengtai district & 0.1158 & 0.3200 & 0 & 1 \\
\hline Changping & $=1$. Changping district & 0.0899 & 0.2861 & 0 & 1 \\
\hline Tongzhou & $=1$. Tongzhou district & 0.0847 & 0.2785 & 0 & 1 \\
\hline Shijingshan & $=1$. Shijingshan district & 0.0514 & 0.2208 & 0 & 1 \\
\hline
\end{tabular}


effects of noise, pollution, and traffic jam problems, we apply the $100 \mathrm{~m}$ to exit (toexits100) dummy variable.

Chinese real estate market is largely influenced and regulated by the government. Starting from 2010 April 30, the Chinese government issued the home purchase restriction (HPR) policy. Followed by the mortgage restriction from 2012 January and 2011 November 11, Beijing Municipal issued a notice that promotes affordable housing in 2012 as priority (The central People's Government of the People's Republic of China, 2011). A new round of tightening real estate market regulation was issued in 2013 February to cool down the market, and in April, Beijing municipal brought up a further real estate control policy by promoting middle-low class owner occupied residential houses and setting restrictions on selling prices, the detailed measurement was finalized in late October 2013 and implemented from 2014 February (Beijing Municipal Commission of the Housing and Urban-Rural Development, 2013, 2014). And dummy variable transaction month is introduced here to control for time and reflects the impact of policies. Detailed descriptive statistics of transaction month see Appendix Figure A1. Dummy variable district is introduced here to control for location and market segregation.

\subsection{Orientation attributes}

The orientation and allocation of the master bedroom and the living room in an apartment constitute the key variables in this paper and they are presented in Table 2.
The different orientation classification for each apartment is based on where on a multifamily building's layout plan the apartment is located. Furthermore, which direction rooms are facing also determine which orientation classification an apartment is given. The above classification of the variables is based on orientation information provided by Lianjia and which have been registered on their website by real estate agents. Figure 1 shows pictures of apartment floorplan layouts.

Our hypothesis is that South the most attractive orientation based on the literature review above. Therefore the South variable constitute the base (benchmark) variable in the econometric models below. The apartments categorized as Southeast, South-north, or Southplus are hypothesized to be less attractive than apartments categorized as South, but still more attractive that the apartments with north and west orientations.

Interestingly, Wang and Li (2006) find that high-income group shows are willing to pay less for apartments with West and North orientations. Therefore we also hypothesize that apartments in the Xisheng district that have West and North orientations have a higher discount than the average apartments sales for the entire data set.

It is interesting to compare the relative attractiveness of South-North axis apartments with East-West axis. As mentioned in the literature review, we are expecting to see that buyers are only willing to buy the East-West oriented apartment with a discount comparing with apartments that are located following the South-north axis.

Table 2. Classification of orientation variables

\begin{tabular}{|c|c|c|c|}
\hline Variable & Description & Mean & Frequency \\
\hline South & $\begin{array}{l}\text { All rooms facing South, the apartment is located at the South of the floorplan under } \\
\text { most circumstances. (Benchmark variable) }\end{array}$ & 0.1703 & 11273 \\
\hline East & $\begin{array}{l}\text { All rooms facing East, the apartment is located at the East of the floorplan under most } \\
\text { circumstances. }\end{array}$ & 0.0336 & 2235 \\
\hline North & $\begin{array}{l}\text { 1) Located at the North of the floorplan and all rooms facing North } \\
\text { 2) Located at the North of the floorplan and more rooms facing north than other } \\
\text { directions }\end{array}$ & 0.0270 & 1794 \\
\hline West & $\begin{array}{l}\text { 1) Located at the west of the floorplan and all rooms facing West } \\
\text { 2) Located at the West of the floorplan and more rooms facing west than other } \\
\text { directions }\end{array}$ & 0.0280 & 1848 \\
\hline Southeast & Located at the southeast of the floorplan & 0.0109 & 723 \\
\hline Southwest & Located at the southwest of the floorplan & 0.0405 & 2693 \\
\hline Northeast & Located at the northeast of the floorplan & 0.0197 & 1303 \\
\hline Northwest & Located at the northwest of the floorplan & 0.0176 & 1176 \\
\hline South-North axis & Layout follows south-north axis and all rooms are located either south or north & 0.5379 & 35102 \\
\hline East-West axis & Layout follows east-west axis and all rooms are located either east or west & 0.0621 & 4142 \\
\hline Southplus & $\begin{array}{l}\text { 1) Located at the south of the floorplan, more rooms facing south } \\
\text { 2) Located at the south of the floorplan, multi-directions (common in multi-bedroom } \\
\text { apartment) }\end{array}$ & 0.0134 & 890 \\
\hline Eastplus & $\begin{array}{l}\text { 1) Located at the east of the floorplan, more rooms facing east than other directions } \\
\text { 2) Located at the East of the floorplan, multi-directions (common in multi-bedroom } \\
\text { apartment) }\end{array}$ & 0.0491 & 3271 \\
\hline Others & Unclassified orientation & 0.0032 & 211 \\
\hline
\end{tabular}

Note: Room here includes master bedroom, living room and guest bedroom (if there is any). See Figure 1 for classification examples. 


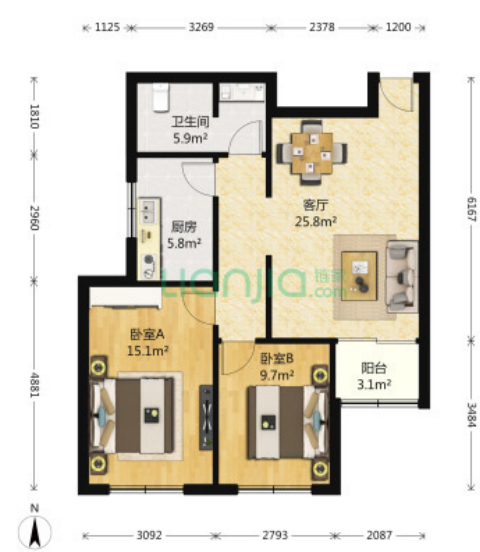

a) South

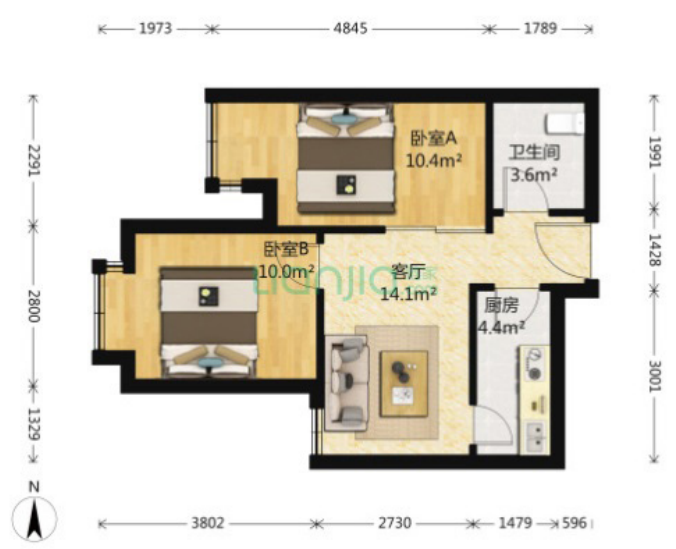

c-1) West type 1

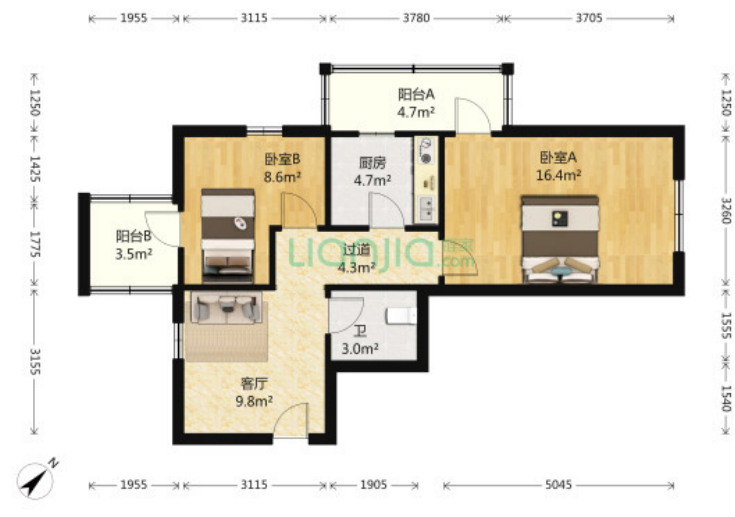

d) Northeast

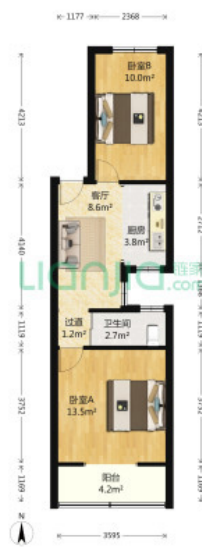

f) South-North axis (both layouts)

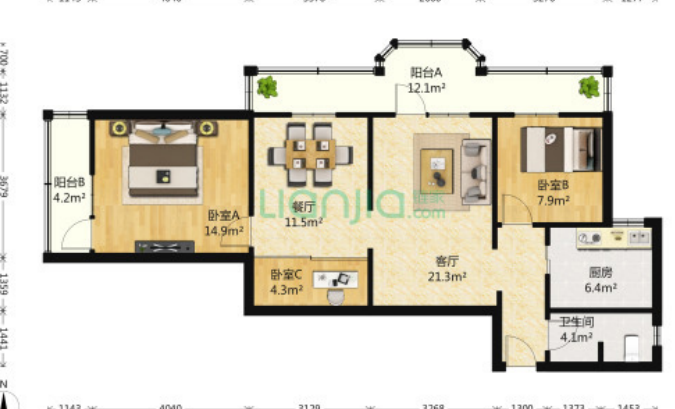

b) North type 2

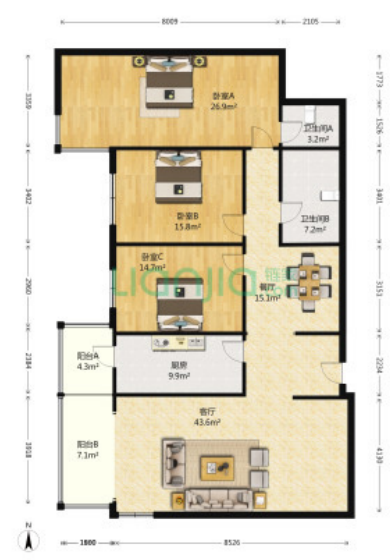

c-2) West type 2

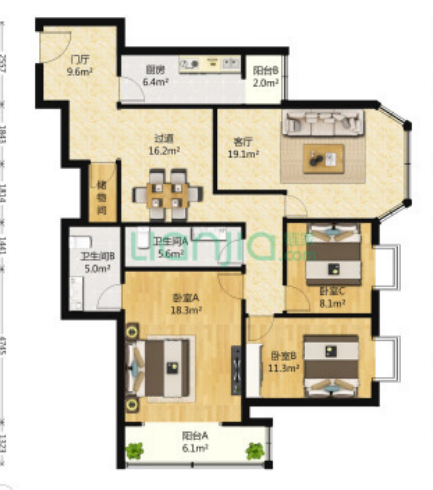

e) Southeast

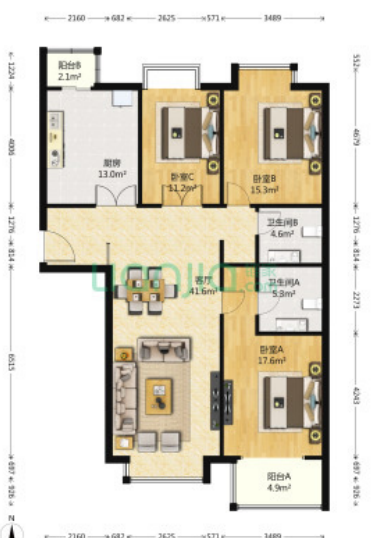



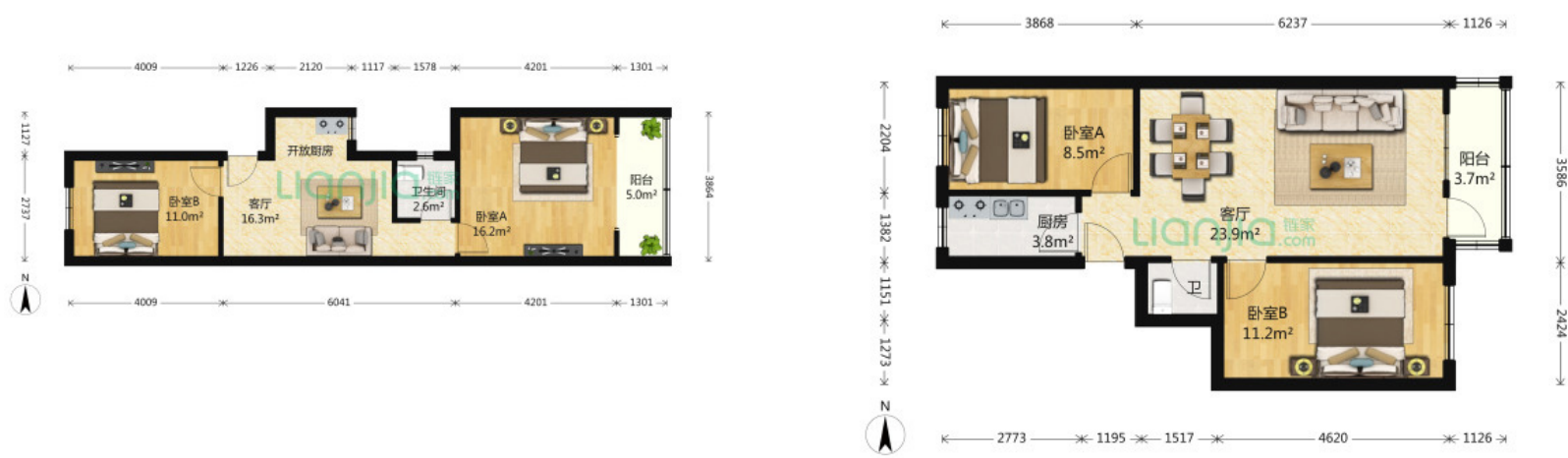

g) East-West axis (both layouts)

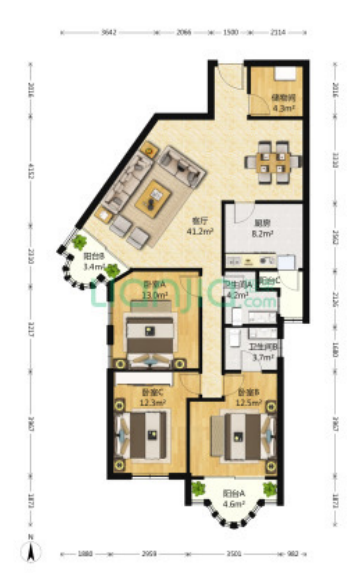

h) Southplus

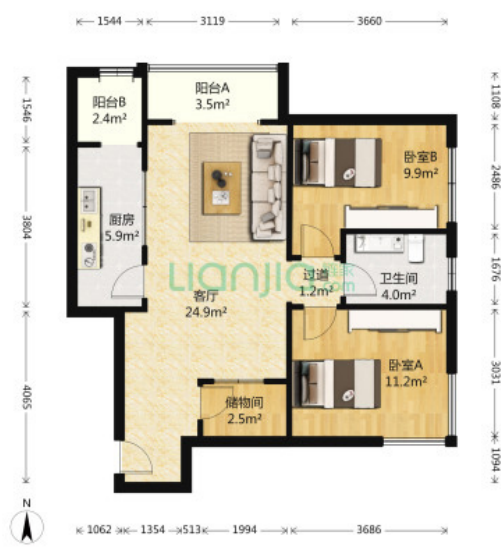

i) Eastplus

Figure 1. Examples of the orientation dummy variables (Source: Lianjia)

\section{Results and discussion}

We apply procedures presented in Fischer and Stirböck (2006) and Elhorst (2010). We start estimating a robust hedonic OLS regression model, which corrects for heteroscedasticity problems. Next we calculate the variance inflation factors (VIF) to detect multicollinearity. The robust OLS model explains $77.54 \%$ of the price variation and the mean VIF is 2.9 as shown in Table 3 . We also examine the spatial dependencies in the OLS model - that is, we test for the existence of spatial autocorrelation by computing the Moran's I.

The Moran's I test statistic is applied to OLS residuals using the spatial weights matrix $k$ nearest neighbor $(k=15)$. The obtained Moran's I is 0.72 , and with a p-value of 0 , we conclude that there is a significant positive spatial autocorrelation.

The overall regression diagnosis statistics of the three spatial econometric models are also presented in Table 3. When the maximum likelihood estimation is calculated, we cannot use $R^{2}$ as the benchmark to check the model's goodness of fit (Maydeu-Olivares \& García-Forero, 2010). Instead, the Akaike information criterion (AIC) is used here. The AIC results suggest that the SDM is preferred, same as log likelihood statistics suggested.
Table 3. Overall diagnosis statistics of the four econometric models applied

\begin{tabular}{|l|c|c|c|c|}
\hline & Linear model & \multicolumn{2}{|c|}{$\begin{array}{c}\text { Spatial } \\
\text { autocorrelation } \\
\text { models }\end{array}$} & $\begin{array}{c}\text { Spatial } \\
\text { Durbin } \\
\text { model }\end{array}$ \\
\hline Statistics & $\begin{array}{c}\text { (a) } \\
\text { OLS(Robust) }\end{array}$ & $\begin{array}{c}\text { (b) } \\
\text { SAR(lag) }\end{array}$ & $\begin{array}{c}\text { (c) } \\
\text { SAR(err) }\end{array}$ & $\begin{array}{c}\text { (d) } \\
\text { SDM }\end{array}$ \\
\hline$R^{2}$ & 0.78 & $\begin{array}{c}\text { Rho: } \\
0.78\end{array}$ & $\begin{array}{c}\text { Lambda: } \\
0.88\end{array}$ & \\
\hline VIF & 2.90 & & & \\
\hline Moran's I & 0.72 & & & \\
\hline Log- & & 39064 & 44546 & 45178 \\
Likelihood & & -77978 & -88943 & -90062 \\
\hline AIC & & & &
\end{tabular}

Notes: The number of observations is 63 306. Spatial weights matrix $k$ nearest neighbor $(\mathrm{KNN})$ with $k=15$, Beijing housing market. AIC $=$ Akaike information criterion; OLS = ordinary least squares; SAR(err) = spatial autoregressive error; $\operatorname{SAR}(\mathrm{lag})=$ spatial autoregressive lag; $\mathrm{SDM}=$ spatial Durbin model.

\subsection{Basic independent variables}

The results of the estimated OLS and SDM of the basic independent variables are presented in Table 4 for overall study area and Xicheng district. 


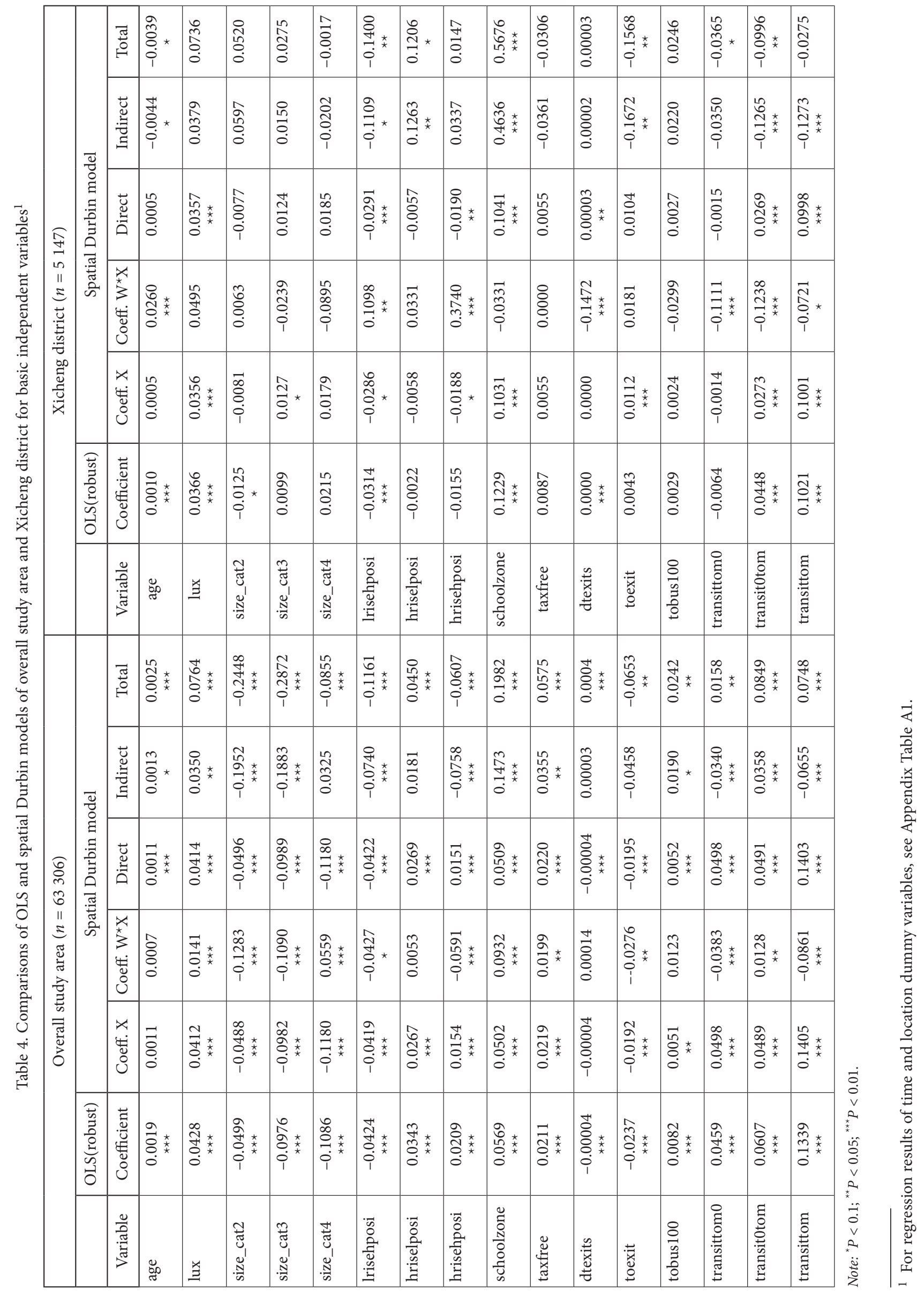


The left half of Table 4 (Overall Study Area) presents the result of basic independent variables of OLS and Spatial Durbin model for the overall study area, which contains 63306 observations covering 10 districts from October 2011 to September $2014 .^{2}$ There are five sub-columns of the SDM model: The first sub-column explains the coefficients of explanatory variables $\mathrm{X}$, and the second sub-column explains the coefficients of the spatially lagged independent variable WX, which captures the spatial spillover effect caused by the features of the neighboring properties.

Based on LeSage and Pace's (2010) research, indirect effects could be explained as the spillover impact of a change in a particular variable on the neighboring region. As Moran's I test suggested, only spatial model will be considered. Among the five sub-columns, the direct effect here has more explaining power than the estimated coefficient because the direct effect counts in neighborhood feedback effects as described by LeSage and Pace (2010).

As the dependent variable is a logarithm of PSM, and some of the estimated coefficients are on the dummy variables, a transformation of the anti-log is required to calculate the percentage changes using the formula $\left(\exp ^{\beta_{i}}-1\right){ }^{\star} 100$ (Halvorsen \& Palmquist, 1980). The estimated coefficients for the size dummy variables indicate that small apartment (default is size_cat1) has the highest PSM. For instance, the direct effects of the SDM model shows that apartments that are larger than 144 square meters (variable size_cat4) sell at on average 12.5\% lower PSM compared to studio units (default variable size_cat1).

The estimated coefficients of the floor and position dummy interaction variables (see Table 1 and 4, respectively) show that apartments located at the top position of a low-rise building has the lowest PSM; the estimated direct effect of the variable lrisehposi is negative while the other floor and position variables have positive direct effects. A luxury decoration will lead to an increase of $4.23 \%$ in the property's PSM (variable lux). All estimated parameters are statistically different from zero at a 5\% significance level.

The neighborhood attributes schoolzone and taxfree have positive effects on property prices: apartments that are located in such areas have on average 5.22\% and 2.2\% higher PSM prices, respectively. If the property is within 100 meters of the express way's exit (variable toexit), the noise and air pollution has a negative impact on the PSM of about $2 \%$.

As for locational related variables, transport accessibility matters. The estimated coefficient of variable tobus100 indicates that apartments are sold $0.5 \%$ higher if it is within 100 meters to the nearest bus stop. The interaction dummy variables of metro station and transit inter-junction indicate that apartments that located within

\footnotetext{
2 District dummy variables and transaction month dummy variables are used in the regression to capture the fixed effects for both location and time; the result is displayed in Appendix Table A1.
}

walking distance of the metro station, and the station is also a big transportation transit inter-junction (variable transittom), they are sold about on average 15\% higher comparing with properties that not within 400 meters to the nearest metro.

The OLS and SDM estimations are computed for The Xicheng District (right half of Table 4).

There are only a few direct effects of explanatory variables that still remain significant. Apartment with luxury decorations are still sold with a premium about $3.63 \%$, which is slightly lower than the overall statistics. The advantages of high-rise building are less obvious in this area; apartments that locate in the lower floor in the low-rise building are most valuable (default variable lriselposi, other estimated confidents are all negative). Public transport accessibility plays a less important role comparing with overall study area as Xicheng is the city center (estimated coefficients of variable tobus 100 and transittom0 are no longer significant), but apartment that within 400 meters to metro (variable transit0tom) are still sold with a premium, but if the nearest station is the transit station (variable transittom), the premium dropped to $10.4 \%$ comparing with the overall statistics (15\%). The impact of being in a school zone increases significantly from 5.22\% to $11 \%$ indicates that although Xicheng is one of the most expensive areas but buyers are still willing to pay $6 \%$ extra to be located in a school zone.

\subsection{Orientation attributes}

Our main focus is orientation attributes which consist of dummy variables that are classified into 13 groups (see Table 2 and Figure 1). We let the most attractive orientation category, South, (located at the south of the floorplan and all rooms facing south) to be the base (benchmark) orientation variable. The results presented in the direct effects column for the overall study area in Table 5 shows that the signs of the estimated coefficients of the orientation category variables are as expected. Apartments categorized as Southeast, South-north, and Southplus have discount rates of $1.97 \%, 2.71 \%$, and $2.85 \%$, respectively. The least attractive orientation is Orientation West which has a discount rate as high as $7.8 \%$, and Orientation North apartments have a discount of 7.61\%. Northeast and Northwest orientations are also sold at relatively high discount rates compared to apartments categorized as South: slightly higher than $6 \%$. Furthermore, while the discount of the East-west apartments is $6.13 \%$, the discount is only $2.67 \%$ for the South-North apartments. The difference is about $3.5 \%$.

We see that apartments with West and North orientations categories sell for higher discounts (direct effects) in the Xicheng District, $12.6 \%$ and $9.6 \%$ respectively, as compared to the estimated results based on the overall study area. These results are in line with our discussion that households are Wang and $\mathrm{Li}$ (2006) finding that high income groups show greater concern on unflavored orientations. 


\begin{tabular}{|c|c|c|c|c|c|c|c|c|c|c|c|c|c|c|}
\hline \multirow{7}{*}{ 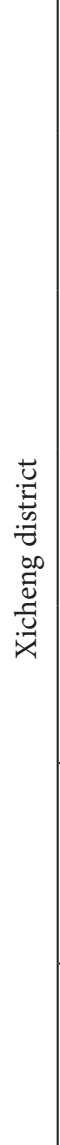 } & \multirow{5}{*}{ 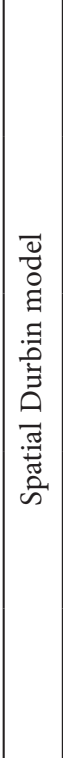 } & 胥 & 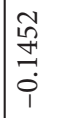 & 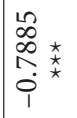 & 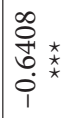 & 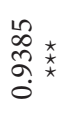 & 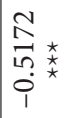 & $\begin{array}{l}\hat{0} \\
\stackrel{0}{0} \\
0 \\
0\end{array}$ & $\begin{array}{l}\infty \\
\infty \\
\stackrel{\infty}{\sharp} \\
\stackrel{0}{*}\end{array}$ & 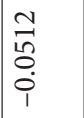 & $\begin{array}{l}\hat{\widehat{a}} \\
\text { Oे } \\
0\end{array}$ & 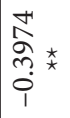 & 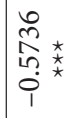 & $\begin{array}{l}\tilde{n} \\
\tilde{n} \\
\tilde{n} \\
i \\
1\end{array}$ \\
\hline & & 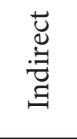 & $\begin{array}{l}\infty \\
\infty \\
o \\
0 \\
i\end{array}$ & 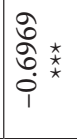 & 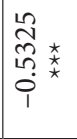 & 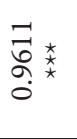 & 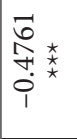 & 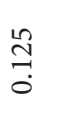 & 荧 & \begin{tabular}{l}
$\stackrel{2}{\Im}$ \\
\multirow{3}{0}{} \\
$\stackrel{0}{0}$ \\
1
\end{tabular} & \begin{tabular}{l}
$\stackrel{7}{1}$ \\
\hdashline
\end{tabular} & 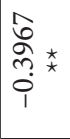 & 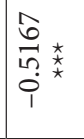 & $\begin{array}{l}\hat{a} \\
\hat{S} \\
10 \\
i \\
i\end{array}$ \\
\hline & & 苛 & 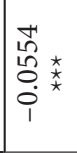 & 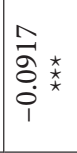 & 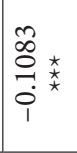 & $\begin{array}{l}\text { त̂ } \\
\text { ठ̀. } \\
\text { i. }\end{array}$ & $\begin{array}{l}\vec{F} \\
\vec{t} \cdot \vec{x} \\
\stackrel{x}{*}\end{array}$ & $\begin{array}{l}\infty \\
\infty \\
0 \\
0 \\
\dot{0}^{*} \\
i^{*}\end{array}$ & 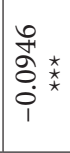 & $\begin{array}{l}0 \\
\infty \\
0 \\
0 \\
0 \\
1\end{array}$ & 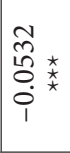 & $\begin{array}{l}0 \\
0 \\
0 \\
0 \\
0 \\
1\end{array}$ & 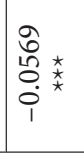 & $\begin{array}{l}20 \\
0 \\
0 \\
0 \\
0 \\
1\end{array}$ \\
\hline & & 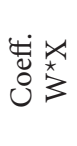 & 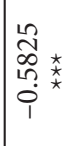 & 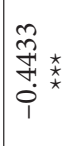 & 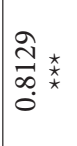 & $\begin{array}{l}\vec{n} \\
\tilde{m}_{0} * \\
\hat{i}^{\prime}\end{array}$ & $\stackrel{\stackrel{\sim}{\pi}}{\underset{\sim}{*}}$ & 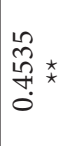 & $\begin{array}{l}\vec{n} \\
\tilde{0} \\
0 \\
0 \\
i\end{array}$ & $\begin{array}{l}\stackrel{\sim}{m} \\
\stackrel{x}{0}\end{array}$ & 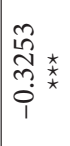 & 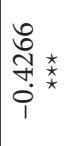 & 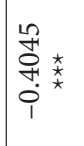 & 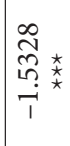 \\
\hline & & 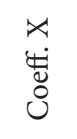 & 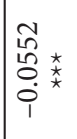 & 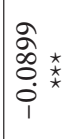 & 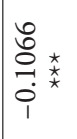 & 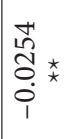 & 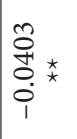 & 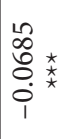 & 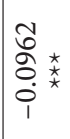 & $\begin{array}{l}1 \\
0 \\
0 \\
0 \\
0 \\
1\end{array}$ & 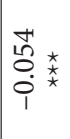 & $\begin{array}{l}\overrightarrow{8} \\
\dot{8} \\
\dot{0}\end{array}$ & 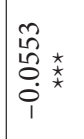 & $\begin{array}{l}\infty \\
0 \\
0 \\
0 \\
0 \\
1\end{array}$ \\
\hline & 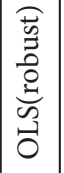 & 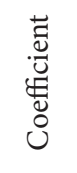 & $\begin{array}{l}\vec{t} \\
\vec{\delta} \\
\dot{0}^{*} \\
\dot{i}^{*}\end{array}$ & 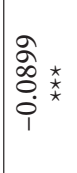 & 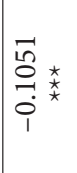 & $\begin{array}{l}\text { त̃ } \\
\text { ठ̊. } \\
\text { i. }\end{array}$ & $\begin{array}{l}\text { बे } \\
\hat{\tilde{O}} \\
\dot{\varphi}^{*}\end{array}$ & 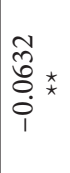 & $\begin{array}{l}\infty \\
\infty \\
0 \\
0 \\
0 . * \\
0 \\
1 \\
1\end{array}$ & $\begin{array}{l}0 \\
\tilde{\delta} \\
8 \\
0 \\
0 \\
1\end{array}$ & 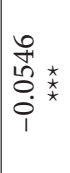 & $\begin{array}{l}0 \\
0 \\
0 \\
0 \\
0 \\
1\end{array}$ & 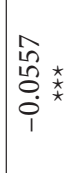 & 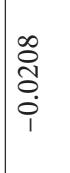 \\
\hline & & 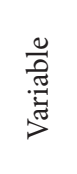 & 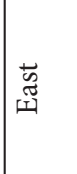 & $\begin{array}{l}\vec{E} \\
\dot{0} \\
z\end{array}$ & 菜 & 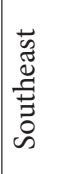 & 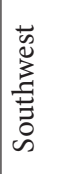 & 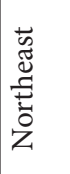 & 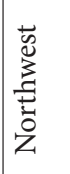 & 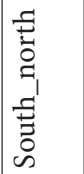 & 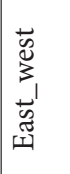 & 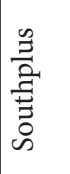 & 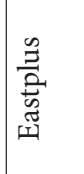 & 岕 \\
\hline \multirow{7}{*}{ 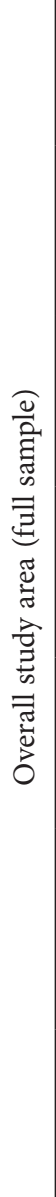 } & \multirow{5}{*}{ 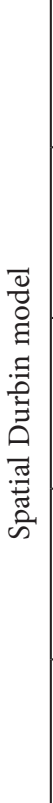 } & $\stackrel{\text { त्ञँ⿺ }}{\stackrel{0}{0}}$ & 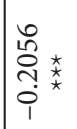 & 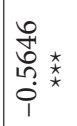 & 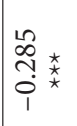 & 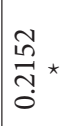 & $\begin{array}{l}\hat{a} \\
\vec{m} \\
\hat{m}^{*} \\
i^{*}\end{array}$ & 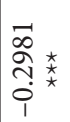 & $\begin{array}{l}0 \\
\vdots \\
0 \\
0 \\
1\end{array}$ & 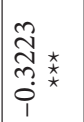 & 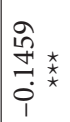 & 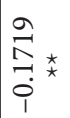 & 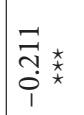 & 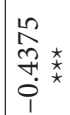 \\
\hline & & $\begin{array}{l}\breve{\sharp} \\
\stackrel{\mathscr{G}}{\Xi} \\
\Xi\end{array}$ & 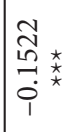 & $\begin{array}{l}\frac{m}{2} \\
\frac{9}{f} \cdot \frac{}{x} \\
i^{*}\end{array}$ & 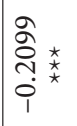 & 拿 & 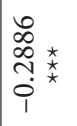 & $\begin{array}{l}\infty \\
\infty \\
\overbrace{n}^{*} \\
\overbrace{1}^{*} \\
i^{*}\end{array}$ & 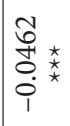 & 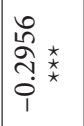 & 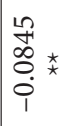 & 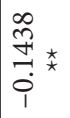 & 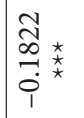 & $\begin{array}{l}\text { Oे. } \\
\text { ò } \\
\text { m. } \\
\text { i }\end{array}$ \\
\hline & & 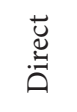 & 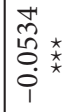 & 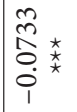 & 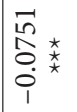 & 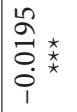 & 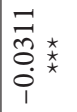 & 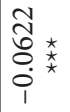 & 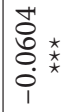 & 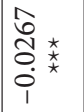 & 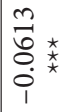 & 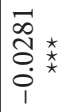 & 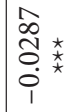 & 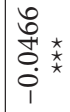 \\
\hline & & 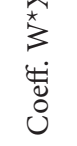 & 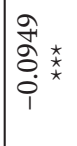 & 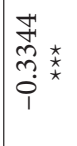 & 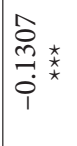 & 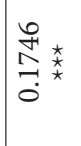 & 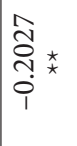 & 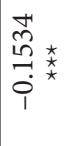 & $\begin{array}{l}\vec{n} \\
0 \\
0 \\
0 \\
1\end{array}$ & 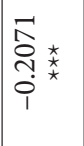 & 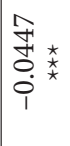 & 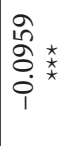 & 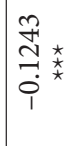 & 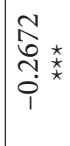 \\
\hline & & $\begin{array}{l}\rtimes \\
\dot{\Psi} \\
\dot{\Xi}\end{array}$ & 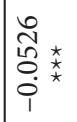 & 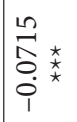 & 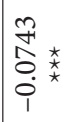 & 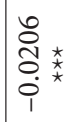 & 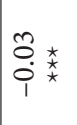 & $\begin{array}{l}m \\
\overrightarrow{8} \\
0^{*} \\
\dot{i}^{*}\end{array}$ & 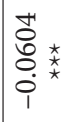 & 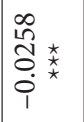 & 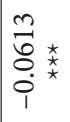 & 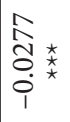 & 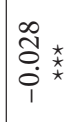 & 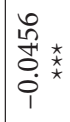 \\
\hline & \multirow[t]{2}{*}{$\begin{array}{l}\overline{\overrightarrow{0}} \\
0 \\
0 \\
0 \\
0 \\
0 \\
0\end{array}$} & 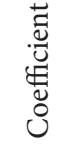 & 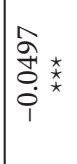 & $\begin{array}{l}\mathcal{I} \\
\hat{A}^{*} \\
\dot{0}^{*} \\
i^{*}\end{array}$ & 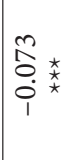 & $\begin{array}{l}\stackrel{0}{0} \\
\dot{\varphi}^{*}\end{array}$ & 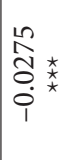 & 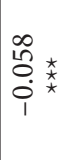 & 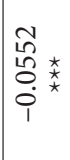 & 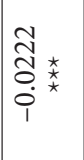 & 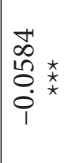 & 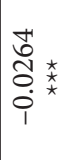 & 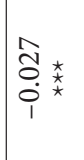 & 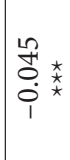 \\
\hline & & 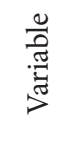 & 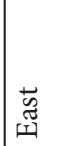 & $\begin{array}{l}\text { F̃ } \\
\text { Zे }\end{array}$ & $\begin{array}{l}\vec{s} \\
3^{\circ}\end{array}$ & 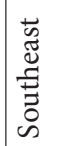 & 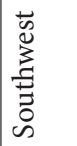 & 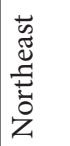 & 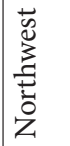 & 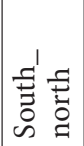 & 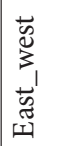 & 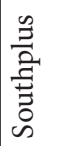 & 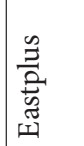 & 离 \\
\hline
\end{tabular}


The degree of willingness to pay for different orientations might change based on building type (low-rise or high-rise) and position of an apartment in a building (lower floor or higher floor) ${ }^{3}$. To test this, we have divided the overall study area into four sub-categories based on the four interaction dummies lriselposi, lrisehposi hriselposi and hrisehposi, and estimated a spatial Durbin econometric models for each of the four sub-samples. Table 6 presents a comparison of the four different estimated direct effects.

The south orientation is the default variable in the four regressions. Since all other orientations have a minus sign, the south orientation can be considered to be the most attractive orientation. As for low-rise building, the results show that the position of an apartment plays a critical role. If the apartments are located in the lower floor, South orientation and other south related orientations apartments have significant price premium comparing with especially West, North, and Northwest orientations. But the advantage of being a pure south-orientated apartment decreases slightly if it is located on the higher floor of a low-rise building. Similar pattern can be found for high-rise buildings as well. West remains to be the least attractive orientation in all cases.

When comparing low-rise buildings with high-rise building, we find that apartments that are located in the lower floor of a building, the discounts for West and North apartments are about similar: 7.5\% for apartments in lowrise buildings and about $6.5 \%$ for apartments in high-rise buildings. Furthermore, the North oriented apartments have the highest discount if they are situated on the lower floor, regardless of type of building. However, apartments with West orientation have the highest discount if they are situated on the higher floor, regardless of building type.

The pattern of discounts with the four separate regressions is close to the pattern obtained in the regression with the full sample and the regression for the Xicheng District.

Our results are in line with the previous researches in the area of climatic, energy and social-cultural aspects. The orientation of the apartments will affect human comfort, heating requirement during winter and air-condition energy consumption during summer. Beijing is located at midlatitudes in the northern hemisphere and is illuminated by the sun from the south. It experiences northerly winds in winter and southeast winds in summer. South and South related apartments may have environmental benefits.

Beside climatic influence of the west facing apartments, the Chinese character for the word west implicitly conjures sadness and represents heaven or hell (mostly) in Buddhism, which might affect home buyers choice. What's more, there are a number of Chinese idioms that reflect the Chinese view on orientation. For example, Chinese people prefer east over west because the sun rises in the east. The Chinese idiom 紫气东来, “the purple air comes

\footnotetext{
3 We have also explored the time-variant preferences for orientations to capture the potential temporal variations by classifying the full sample into four subsamples according to four seasons, however, no clear seasonal willingness to pay variations are detected.
}

Table 6. The impact of type of building, floor and position on orientation attributes

\begin{tabular}{|c|c|c|c|c|}
\hline & \multicolumn{2}{|c|}{ Low-rise building } & \multicolumn{2}{|c|}{ High-rise building } \\
\hline Orientations & $\begin{array}{l}\text { Lower } \\
\text { floor }\end{array}$ & $\begin{array}{l}\text { Higher } \\
\text { floor }\end{array}$ & $\begin{array}{l}\text { Lower } \\
\text { floor }\end{array}$ & $\begin{array}{l}\text { Higher } \\
\text { floor }\end{array}$ \\
\hline East & $-\underset{* \star \star}{0.0561}$ & $\underset{* \star \star}{-0.0483}$ & $\underset{\star \star * \star}{-0.0427}$ & $-\underset{* * *}{-0.0348}$ \\
\hline North & $-\underset{\star * \star}{0.0759}$ & $\underset{\star \star \star}{-0.0339}$ & $\underset{\star \star \star \star}{-0.0641}$ & $-\underset{* * *}{-0.0482}$ \\
\hline West & $\underset{\star x * \star}{-0.0734}$ & $-\underset{* * \star}{-0.0639}$ & $\underset{\star * \star \star}{-0.0639}$ & $\underset{* * \star}{-0.0603}$ \\
\hline Southeast & -0.0154 & 0.0038 & -0.0019 & $\underset{* \star}{-0.0322}$ \\
\hline Southwest & $\underset{\star \star \star \star}{-0.0272}$ & $\underset{* *}{-0.0250}$ & $\underset{\star * \star}{-0.0188}$ & $-\underset{* * *}{-0.0345}$ \\
\hline Northeast & $-\underset{* * \star}{-0.0590}$ & $\underset{*}{-0.0283}$ & $\underset{\star \star * \star}{-0.0617}$ & $-\underset{* * \star}{-0.0512}$ \\
\hline Northwest & $-\underset{* * \star}{-0.0624}$ & $\underset{* \star}{-0.0384}$ & $\underset{\star * \star}{-0.0513}$ & $-\underset{* * *}{0.0540}$ \\
\hline Southnorth & $-\underset{* * \star}{-0.0254}$ & $\underset{* * \star}{-0.0329}$ & -0.0054 & -0.0090 \\
\hline Eastwest & $-\underset{* \star *}{0.0641}$ & $-\underset{\star \star \star \star}{0.0544}$ & $-\underset{\star * \star}{0.0560}$ & $-\underset{* * *}{-0.0314}$ \\
\hline Southplus & -0.0022 & $\underset{\star \star \star \star}{-0.0394}$ & 0.0017 & $-\underset{* * *}{-0.0395}$ \\
\hline Eastplus & $-\underset{* \star \star}{0.0354}$ & $-\underset{\star * \star}{0.0268}$ & $-\underset{\star * \star}{0.0233}$ & $\underset{*}{-0.0168}$ \\
\hline Others & -0.0077 & $\underset{\star \star * \star}{-0.0838}$ & -0.0298 & -0.0294 \\
\hline No of obs. & 21644 & 15007 & 17624 & 9031 \\
\hline
\end{tabular}

Note: ${ }^{\star} \mathrm{P}<0.1 ;{ }^{* *} \mathrm{P}<0.05 ;{ }^{* * *} \mathrm{P}<0.01$. Spatial Durbin model, direct effect comparisons from four regressions.

from the east," is interpreted as a propitious omen. By contrast, the direction west implies a disconsolate feeling, with the Chinese idioms 归西, “go west”, and 驾鹤西去, "riding a crane to the West", serving as euphemisms for people who have passed away.

Furthermore, according to local real estate brokers we have interviewed, west-oriented apartments are avoided by Chinese businessman, and some even refuse to enter a pure west-oriented apartment. They are considering a traditional Chinese idiom called 日落西山, by characters it means "sun, fall, west, hill". However the meaning of this idiom means "an elderly is dying" or "things decay".

Although a number of basic independent variable for overall study area and Xicheng disctrict has changed from significant to insignificant, the result of the orientation dummy variables of years. The result of Xicheng district coincide with Wang and Li (2006) that high-income (high-wealth) group shows greater concern for west-facing apartments remains mostly significant especially for orientations such as West, North and Northwest which required a higher discount.

As Table 6 reveals, the impact of floor and position in building on the willingness to pay for different orientations varies. Consider for instance a 6 -storey low rise building 
(such as former affordable housing, social welfare housing and early commodity residential buildings). Many of these buildings are located in areas where the surrounding buildings commonly have the same height, and between two rows of buildings, there may be a flower bed or a row of trees, or more often a crowded roadside parking lot. If an apartment is located on the lower floor, the South orientated have best chances to enjoy a longer time of sunshine, while North and West oriented apartments might suffer from more darkness and higher dampness.

For higher floor apartments in both low-rise and high rise buildings, the willingness to pay for apartments that are pure south-oriented is marginally lower, compared to lower-floor apartments. When buildings in an area are of similar height (which is common in Beijing), buyers who purchase higher-floor apartments have a higher chance of having a better view, better ventilation and brighter indoor light, regardless of orientation.

But at the same time, high-floor apartments in highrise buildings are more likely to be negatively affected by harsh winter climate, and all wind from the north and the north-west, both north and west oriented apartments are less attractive, however, winter heating is mostly centralized and the cost is charged by size of the apartments regardless of orientations. However, the electricity cost various substantially in the summer, especially for westoriented apartments which are much exposed to direct strong west sun in the higher floor in high-rise buildings.

\section{Conclusions}

In this paper, we estimate the willingness of buyers to pay for different orientations on residential apartments in Beijing using 13 orientation dummy variables.

We use a data set comprising 63306 private secondary residential transactions recorded by certified agents in 10 districts and 161 sub-districts located within the Sixth Ring Road of Beijing from October 2011 to September 2014. All records are listed online with information on the buildings' GIS location and processing agents. To the best of our knowledge, this is the most comprehensive and most recent data set ever used in any working paper or article.

A semi-logarithmic transformation of the price per square meter (PSM) is applied as the dependent variable. In terms of explanatory variables, we consider 72 variables, which include structural, neighborhood, locational, and orientation variables.

To find the most appropriate model, we start with the OLS model and test for both spatial dependence and spatial autocorrelation as they are common problems for properties. The value of Moran's I is 0.72 , suggesting highly significant spatial dependence and autocorrelation among neighbors. We then employed the most commonly used spatial models: spatial lag, spatial error and spatial Durbin models. AIC and Log-likelihood suggested that SDM fits better. Moreover, the SDM allows us to investigate the direct and indirect effects of explanatory variables.

According to our results, most of the structural variables are significant and all the orientation variables are significant. Orientation South is the default (base) orientation variable and all other orientation variables have negative coefficients, suggesting that buyers are willing to pay the most for a purely south-oriented apartments with all rooms facing south, followed by other south related orientations. A west-oriented unit is the most disliked unit, with a 7.8\% discount compared to south-oriented apartments.

Generally, the preference pattern of orientation for apartments in the Xicheng District is similar as the overall study area. However, buyers in Xicheng District have an even greater aversion to west-facing units, with a discount of $12.6 \%$ compared with $7.8 \%$ for the overall study area, which means that buyers in Xicheng District have a greater willingness to pay extra for a dwelling with good orientation and to demand an extra discount for a dwelling that have less desirable orientations.

We have also studied if buyers' preferences for orientation also are affected by the height of the building (lowrise or high-rise) and which floor position (high or low position) an apartment has in a building by estimating separate four regressions. The size of the discounts is close to the pattern of discounts obtained in this regression with the full sample. For higher floor apartments in both lowrise and high rise buildings, the willingness to pay for a pure south-oriented apartment is marginally lower, compared to lower-floor apartments.

Architects and building planners may wish to take our findings into consideration in their design of properties and neighborhoods. Developers could make a better selection among the different allocation strategies with apartments with various orientations to receive a higher selling price and achieve a maxim profit. Meanwhile, home seekers and real estate brokers could adjust expectations based on research results.

\section{References}

Andersen, P. H., Cook, N., \& Marceau, J. (2004). Dynamic innovation strategies and stable networks in the construction industry: implanting solar energy projects in the Sydney Olympic Village. Journal of Business Research, 57(4), 351-360. https://doi.org/10.1016/S0148-2963(02)00391-0

Andersson, D. E., Shyr, O. F., \& Fu, J. (2010). Does high-speed rail accessibility influence residential property prices? Hedonic estimates from southern Taiwan. Journal of Transport Geography, 18(1), 166-174. https://doi.org/10.1016/j.jtrangeo.2008.10.012

Anselin, L. (1988). Lagrange multiplier test diagnostics for spatial dependence and spatial heterogeneity. Geographical Analysis, 20(1), 1-17. https://doi.org/10.1111/j.1538-4632.1988.tb00159.x

Beijing Municipal Commission of the Housing and Urban-rural Development. (2013). Guanyu 《Beijingshi zizhuxing shangpinfang xiaoshou guanli zanxing guiding (zhengqiu yijiangao)》gongkai zhengqiu yijian de tongzhi [Circular on seeking public opinions on the rules on provisional regulations on the administration of sales of owner-occupied commodity housing in Beijing]. Retrieved from http://www.bjjs.gov.cn/ bjjs/xxgk/yjzj/318757/index.shtml

Beijing Municipal Commission of the Housing and Urban-rural Development. (2014). Beijingshi zhuangfang he chengxiang jianshe weiyuanhui yuanyu yinfa 《Beijingshi zizhuxing shang- 
pin zhufang xiaoshou guanli zanxing guiding》de tongzhi [Circular on printing and distributing "The Interim provisions on the administration of sales of owner-occupied commodity housing in Beijing"]. Retrieved from http://www.bjjs. gov.cn/bjjs/xxgk/gfxwj/zfcxjswwj/315355/index.shtml

Benson, E. D., Hansen, J. L., Schwartz, A. L., \& Smersh, G. T. (1998). Pricing residential amenities: the value of a view. The Journal of Real Estate Finance and Economics, 16(1), 55-73. https://doi.org/10.1023/A:1007785315925

Black, S. E. (1999). Do better schools matter? Parental valuation of elementary education. Quarterly Journal of Economics, 577599. https://doi.org/10.1162/003355399556070

Bouillot, J. (2008). Climatic design of vernacular housing in different provinces of China. Journal of Environmental Management, 87(2), 287-299. https://doi.org/10.1016/j.jenvman.2006.10.029

Chin, T.-L., Chau, K. W., \& Ng, F. F. (2004). The Impact of the Asian financial crisis on the pricing of condominiums in Malaysia. Journal of Real Estate Literature, 12(1), 33-49. https://doi.org/10.5555/reli.12.1.j884n3j560n601qu

Clark, D. E., \& Cosgrove, J. C. (1990). Hedonic prices, identification, and the demand for public safety. Journal of Regional Science, 30(1), 105-121.

https://doi.org/10.1111/j.1467-9787.1990.tb00083.x

Colwell, P. F., \& Dilmore, G. (1999). Who was first? An examination of an early hedonic study. Land Economics, 620-626. https://doi.org/10.2307/3147070

Court, A. T. (1939). Hedonic price indexes with automotive examples. In The dynamics of automotive demand (pp. 99-117). New York: General Motors.

Di, M., \& Xiao, Y. (1987). Jingshen wenming jianshe zhong de Xicheng qu [The social construction of spiritual civilization in Xicheng District]. Xuexi yu yanjiu, 6, 31.

EBeijing, the Official Website of the Beijing Government. (2012). Best pay in Beijing Xicheng district, Beijing News update, Beijing Information. Retrieved from http://www.ebeijing.gov.cn/ BeijingInformation/BeijingNewsUpdate/t1237763.htm

Elhorst, J. P. (2010). Applied spatial econometrics: raising the bar. Spatial Economic Analysis, 5(1), 9-28.

https://doi.org/10.1080/17421770903541772

Fadaei, S., Iulo, L. D., \& Yoshida, J. (2015). The effects of orientation and elongation on the price of the homes in Central Pennsylvania. EEHR, IAH, Penn State University, Dept. of Architecture. Retrieved from http://www.personal.psu.edu/ juy18/index_files/Full_Paper_ICCCBE2016_16Dec2015.pdf

Fischer, M. M., \& Stirböck, C. (2006). Pan-European regional income growth and club-convergence: insights from a spatial econometric perspective. Annals of Regional Science, 40(4), 693-721. https://doi.org/10.1007/s00168-005-0042-6

Follain, J. R., \& Jimenez, E. (1985). Estimating the demand for housing characteristics: a survey and critique. Regional Science and Urban Economics, 15(1), 77-107. https://doi.org/10.1016/0166-0462(85)90033-X

Gao, X., \& Asami, Y. (2011). Preferential size of housing in Beijing. Habitat International, 35(2), 206-213. https://doi.org/10.1016/j.habitatint.2010.09.002

Griliches, Z. (1958). The demand for fertilizer: an economic interpretation of a technical change. Journal of Farm Economics, 40(3), 591-606. https://doi.org/10.2307/1235370

Griliches, Z. (1961). Hedonic price indexes for automobiles: an econometric of quality change. In The price statistics of the federal government (pp. 173-196). NBER.

Gu, H., \& Ryan, C. (2008). Place attachment, identity and community impacts of tourism - the case of a Beijing hutong. Tourism Management, 29(4), 637-647.

https://doi.org/10.1016/j.tourman.2007.06.006
Guo, Q., \& Guo, Q. (2001). The formation and early development of architecture in Northern China. Construction History, 17(1), 3-16. Retrieved from http://www.jstor.org/stable/41613827

Guo, F., \& Wang, S. (2008). Shanghai gaoceng zhuzhai ziran tongfeng jieneng sheji yanjiu [The usage of natural ventilation in the energy-saving design of high-rise buildings in Shanghai]. Jianzhu xuebao, 11, 47-49.

Haas, G. C. (1922). Sale prices as a basis for farm land appraisal. Technical Bulletin 9. St. Paul: The University of Minnesota Agricultural Experiment Station.

Halvorsen, R., \& Palmquist, R. (1980). The interpretation of dummy variables in semilogarithmic equations. American Economic Review, 70(3), 474-475. Retrieved from http://www. jstor.org/stable/1805237

Harrison Jr, D., \& Rubinfeld, D. L. (1978). Hedonic housing prices and the demand for clean air. Journal of Environmental Economics and Management, 5(1), 81-102. https://doi.org/10.1016/0095-0696(78)90006-2

Hite, D., Chern, W., Hitzhusen, F., \& Randall, A. (2001). Property-value impacts of an environmental disamenity: the case of landfills. Journal of Real Estate Finance and Economics, 22(2-3), 185-202. https://doi.org/10.1023/A:1007839413324

Jin, M. (1981). Kexue pingjia rizhao, gaijin dongxi xiang zhuzhai sheji [Scientific evaluation of sunshine and the improvement of design of East-West oriented residential apartments]. Jianzhu xuebao, 6, 6.

Kain, J. F., \& Quigley, J. M. (1970). Measuring the value of house quality. Journal of the American Statistical Association, 65(330), 532-548. https://doi.org/10.1080/01621459.1970.10481102

Kim, D. K. (2006). The natural environment control system of Korean traditional architecture: comparison with Korean contemporary architecture. Building and Environment, 41(12), 1905-1912. https://doi.org/10.1016/j.buildenv.2005.07.007

Lancaster, K. J. (1966). A new approach to consumer theory. Journal of Political Economy, 74(2), 132-157. https://doi.org/10.1086/259131

LeSage, J. (2015). Spatial econometrics. In C. Karlsson, M. Andersson, \& T. Norman (Eds.), Handbook of research methods and applications in economic geography. Edward Elgar. https://doi.org/10.4337/9780857932679.00007

LeSage, J. P., \& Pace, R. K. (2010). Spatial econometric models. In M. M. Fischer, \& A. Getis (Eds.), Handbook of applied spatial analysis: software tools, methods and applications. Springer Berlin Heidelberg. https://doi.org/10.1007/978-3-642-03647-7_18

Li, W. (2016). Fengshuixue yingxiang xia de gudian yuanlin sheji yanjiu [The influence of Feng-Shui on classical Chinese garden designs]. Lvse keji, 5.

Li, Z., \& Jiang, Y. (2006). Beijingshi zhuzhai kongtiao fuhe he haoneng texing yanjiu [Study the characteristics of air conditioning's load and energy consumption of residential apartments in Beijing]. Nuantong kongtiao, 8(15).

Liu, H. (1964). Dui jiejue chengshi zhuzhai xishai wenti de tanjiu [Discussion on solving the west sun problem in the urban residential apartments]. Jianzhu Xuebao, 1(31).

Liu, M., Ren, J., \& Lian, C.(2018). Hanleng diqu ji you zhuzhai shinei re huanjing yanjiu [Study on indoor thermal environment of existing residential buildings in cold area]. Diwen jianzhu jishu, 40(6), 144-151.

Liu, P. (1996). Fengshui moshi de dilixue pingjia [The evaluation of Feng-Shui model in geography]. Renwen Dili, 11(1), 36-39.

$\mathrm{Lu}, \mathrm{J}$. (2018). The value of a south-facing orientation: a hedonic pricing analysis of the Shanghai housing market. Habitat International, 81, 24-32. https://doi.org/10.1016/j.habitatint.2018.09.002

Lu, S. J., \& Jones, P. B. (2000). House design by surname in Feng Shui. Journal of Architecture, 5(4), 355-367. https://doi.org/10.1080/13602360050214386 
Mak, M. Y., \& Ng, S. T. (2005). The art and science of Feng Shui - a study on architects' perception. Building and Environment, 40(3), 427-434. https://doi.org/10.1016/j.buildenv.2004.07.016

Malpezzi, S. (2003). Hedonic pricing models: a selective and applied review. In T. O’Sullivan, \& K. Gibb (Eds.), Housing economics and public policy: essays in honor of Duncan Maclennan. Oxford: Blackwell Science.

Metzner, S., \& Kindt, A. (2018). Determination of the parameters of automated valuation models for the hedonic property valuation of residential properties: a literature-based approach. International Journal of Housing Markets and Analysis, 11(1), 73-100. https://doi.org/10.1108/IJHMA-02-2017-0018

Meng, M. (1985). Dongxi xiang zhuzhai kequxing tantao [Discussion on the desirability of East-West oriented residential apartments]. Zhuzhai keji, 5, 1.

Meyer, J. F. (1978). "Feng-Shui" of the Chinese city. History of Religions, 18(2), 138-155. https://doi.org/10.1086/462811

Nelson, J. P. (2008). Hedonic property value studies of transportation noise: aircraft and road traffic. In Hedonic methods in housing markets (pp. 57-82). New York, NY: Springer. https://doi.org/10.1007/978-0-387-76815-1_4

Oates, W. E. (1969). The effects of property taxes and local public spending on property values: an empirical study of tax capitalization and the Tiebout hypothesis. Journal of Political Economy, 77(6), 957-971. https://doi.org/10.1086/259584

Osland, L. (2010). An application of spatial econometrics in relation to hedonic house price modeling. Journal of Real Estate Research, 32(3), 289-320.

https://doi.org/10.5555/rees.32.3.d4713v80614728x1

Ottensmann, J. R., Payton, S., \& Man, J. (2008). Urban location and housing prices within a hedonic model. Journal of Regional Analysis and Policy, 38, 19-35. Retrieved from https:// ideas.repec.org/a/ags/jrapmc/132338.html

Ren, Z., Foliente, G., Chan, W., Chen, D., \& Syme, M. (2011, November). AusZEH design: software for low-emission and zero-emission house design in Australia. In Proceeding of Building Simulation. Retrieved from http://ibpsa.org/proceedings/BS2011/P_1121.pdf

Ridker, R. G., \& Henning, J. A. (1967). The determinants of residential property values with special reference to air pollution. The Review of Economics and Statistics, 49(2), 246-257. https://doi.org/10.2307/1928231

Rosen, S. (1974). Hedonic prices and implicit markets: product differentiation in pure competition. Journal of Political Economy, 82(1), 34-55. https://doi.org/10.1086/260169

Sheppard, S. (1999). Hedonic analysis of housing markets. In P. Cheshire, \& E. S. Mills (eds.), Handbook of regional and urban economics: Vol. 3. Applied urban economics. Place: NorthHolland. https://doi.org/10.1016/S1574-0080(99)80010-8

Sidi, N. S. S. (2010). Quality affordable housing: a theoretical framework for planning and design of quality housing. Journal of Techno Social, 2(1). Retrieved from http://penerbit. uthm.edu.my/ojs/index.php/JTS/article/view/314/193

Sui,Q., Wang, C., \& He, W. (2014). Zhuzhai xixiang fangjian kaichuang dui ziran caiguang de yingxiang yanjiu [The study on the influence of nature lighting in residential west room by window design]. Huazhong jianzhu, 5 .

Tan, T. H. (2012). Meeting first-time buyers' housing needs and preferences in greater Kuala Lumpur. Cities, 29(6), 389-396. https://doi.org/10.1016/j.cities.2011.11.016

The Central People's Government of the People's Republic of China. (2011). Beijingshi 2012 nian shangpinfang touzi jihua youxian tuijin baozhangfang jianshe [Beijing's 2012 residential housing investment plan will give priority to the construc- tion of affordable housing]. Retrieved from http://www.gov. cn/jrzg/2011-11/11/content_1990885.htm

Thongkamsamut, C., \& Buranakarn, V. (2007). Form follows Feng Shui. Nakhara: Journal of Environmental Design and Planning, 2, 37-54. Retrieved from http://www.aj.arch.chula. ac.th/nakhara/files/article/155-351-1-PB.pdf

Tobler, W. R. (1970). A computer movie simulating urban growth in the Detroit region. Economic Geography, 46, 234240. https://doi.org/ 10.2307/143141

Wallace, H. A. (1926). Comparative farm-land values in Iowa. The Journal of Land \& Public Utility Economics, 2(4), 385-392. https://doi.org/10.2307/3138610

Wang, D., \& Li, S. M. (2004). Housing preferences in a transitional housing system: the case of Beijing, China. Environment and Planning A, 36(1), 69-87. https://doi.org/10.1068/a35263

Wang, D., \& Li, S. M. (2006). Socio-economic differentials and stated housing preferences in Guangzhou, China. Habitat International, 30(2), 305-326.

https://doi.org/10.1016/j.habitatint.2004.02.009

Waugh, F. V. (1929). Quality as a determinant of vegetable prices: a statistical study of quality factors influencing vegetable prices in the Boston wholesale market (No. 312). New York: Columbia University Press; London: PS King \& son, Limited. https://doi.org/10.7312/waug92494

Wei, X., (2007). Ruhe jiejue dongxi chaoxiang zhuzhai de xishai wenti [How to solve the west sun problem for East-West oriented apartments]. Zhongwai Jianzhu, 9.

Wen, H., Bu, X., \& Qin, Z. (2014). Spatial effect of lake landscape on housing price: a case study of the West Lake in Hangzhou, China. Habitat International, 44, 31-40.

https://doi.org/10.1016/j.habitatint.2014.05.001

Weng, Y. (2008). Shanghai Anting xinzhen guihua jianshe de jingyan jiejian he wenti sikao [The experiences and considerations of Shanghai Anting New Town's planning and construction]. Shanghai chengshi guihua, 2, 33-38.

Xiao, Y. (2017). Hedonic housing price theory review. In Urban morphology and housing market (pp. 11-40). Singapore: Springer. https://doi.org/10.1007/978-981-10-2762-8_2

$\mathrm{Xu}, \mathrm{P}$. (1997). Feng-shui as clue: identifying prehistoric landscape setting patterns in the American Southwest. Landscape Journal, 16(2), 174-190. https://doi.org/10.3368/lj.16.2.174

$\mathrm{Xu}$, P. (1998). "Feng-Shui" models structured traditional Beijing courtyard houses. Journal of Architectural and Planning Research, 15(4), 271-282. Retrieved from https://www.jstor.org/ stable/43030469

$\mathrm{Xu}, \mathrm{X}$. (2009). Qianlun jianzhu fengshui wenhua de neihan yu shiyong gongneng [A brief discussion of cultural and practical functions on the Feng-Shui architecture design]. Zhongwai jianzhu, 9, 95-96.

Zeng, Z., \& Ping, R. (2007). Zhuzhai dongxixiang de sheji tantao [Discussion on the architectural design of East-West oriented residential apartments]. Jiangxi jiancai, 1, 32-33.

Zhang, D. (2016). Juer Hutong new courtyard housing in Beijing: a review from the residents' perspective. International Journal of Architectural Research, 10(2).

https://doi.org/10.26687/archnet-ijar.v10i2.963

Zhang, X. (2006). "Nan" zi suyuan ji qi wenhua yiyun [The traceability of character 'South' and its cultural implication]. Shehui kexuejia, 2, 206-208.

Zhang, Y. (1990). Wei dongxi chaoxiang duoceng zhuzhai zheng yixizhidi [Arguing the suitability of East-West oriented apartments in a multi-storey residential building]. Zhuzhai keji, $2,19$. 


\section{Appendix}

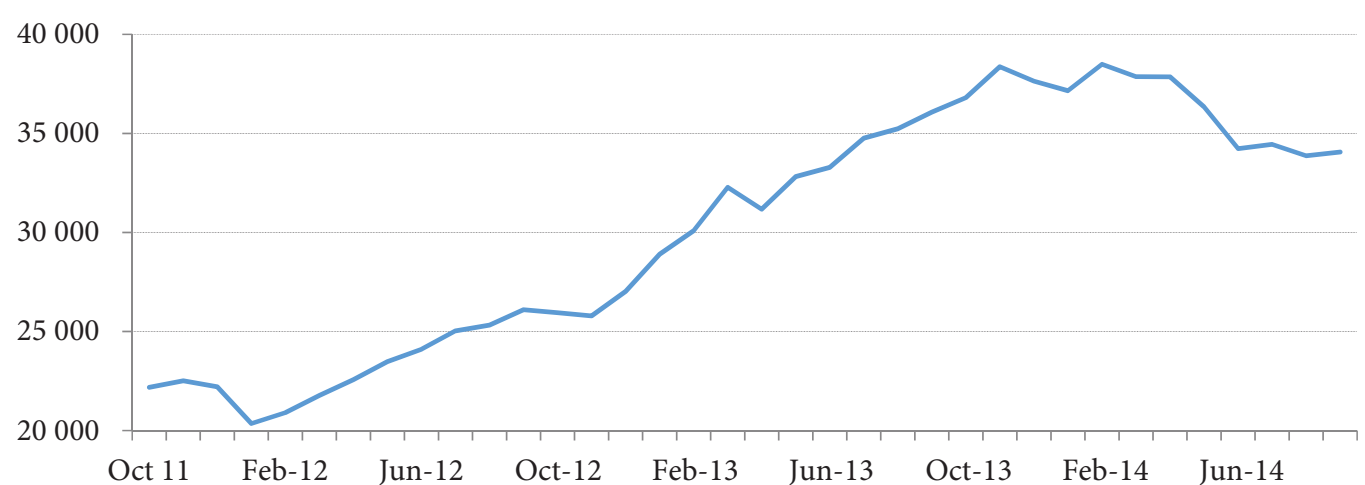

Figure A1. Mean average PSM for each month from Oct 2011 to Sep 2014

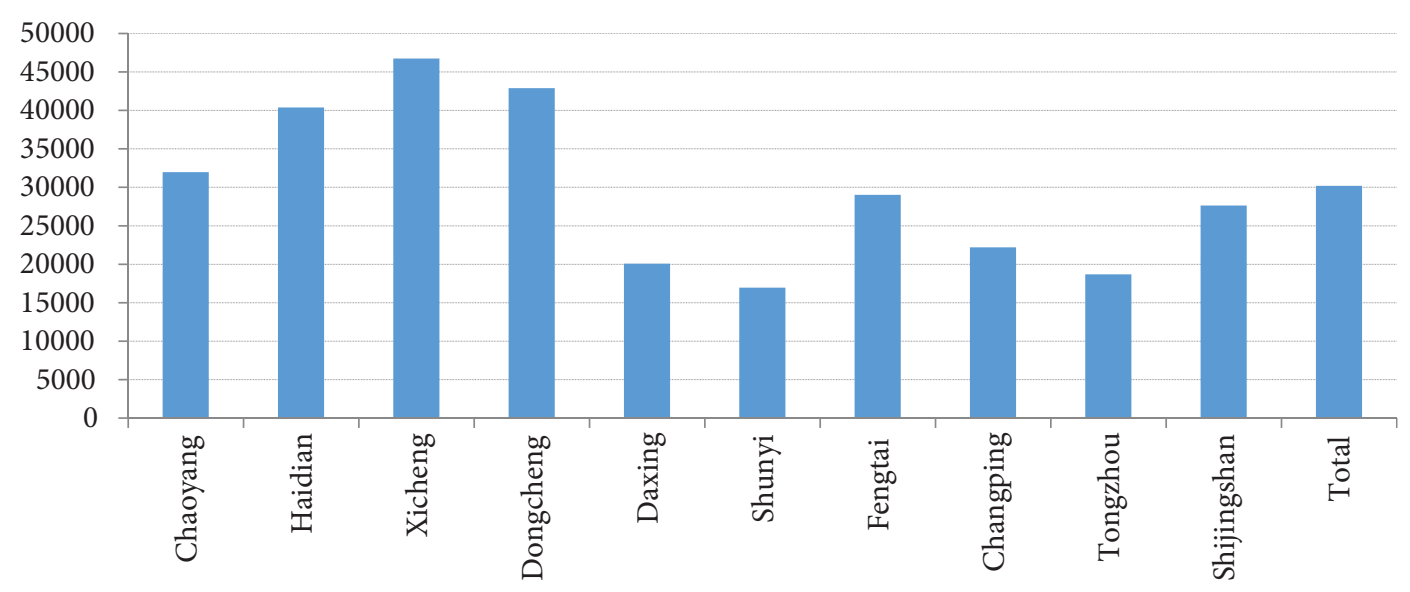

Figure A2. Mean average PSM for each district from Oct 2011 to Sep 2014

Table A1. Results of location dummy variables for overall study area. The base variable is Chaoyang district

\begin{tabular}{|c|c|c|c|c|c|c|}
\hline & OLS(robust) & \multicolumn{5}{|c|}{ Spatial Durbin model } \\
\hline District & Coeff. & Coeff. & $\mathrm{W}^{\star}$ Coeff. & Direct & Indirect & Total \\
\hline Haidian & $\underset{* * \star}{0.2257}$ & $\underset{* * \star}{0.2268}$ & $-\underset{\star * \star}{0.1050}$ & $\underset{* * *}{0.2267}$ & $\underset{* \star *}{-0.0581}$ & $\underset{* * *}{0.1686}$ \\
\hline Xicheng & $\underset{* * \star}{0.3413}$ & $\underset{* * *}{0.3472}$ & $-\underset{\star \star \star \star}{0.1757}$ & $\underset{* * *}{0.3467}$ & $-\underset{\star \star \star \star}{-0.1094}$ & $\underset{* * *}{0.2373}$ \\
\hline Dongcheng & $\underset{* \star \star}{0.2576}$ & $\underset{* * \star}{0.2539}$ & $-\underset{\star \star \star \star}{0.1150}$ & $\underset{* * \star}{0.2537}$ & $-\underset{\star * \star}{0.0616}$ & $\underset{* * *}{0.1921}$ \\
\hline Daxing & $\begin{array}{c}-0.4076 \\
\star * \star\end{array}$ & $\begin{array}{c}-0.3984 \\
* * *\end{array}$ & $\underset{* * \star}{0.1019}$ & $-\underset{* * *}{-0.3984}$ & -0.0116 & -0.4101 \\
\hline Shunyi & $\underset{* * \star}{-0.4796}$ & $\underset{* * *}{-0.4722}$ & $\underset{* * *}{0.1235}$ & $-\underset{* * *}{-0.4722}$ & -0.0096 & -0.4818 \\
\hline Fengtai & $-\underset{\star * \star}{0.0893}$ & $\underset{* * *}{-0.0798}$ & -0.0009 & $\underset{* * \star}{-0.0797}$ & $\underset{\star \star \star \star}{-0.0317}$ & -0.1114 \\
\hline Changping & $-\underset{\star \star * \star}{-0.2130}$ & $-\underset{* \star \star}{-0.2044}$ & $\underset{* * *}{0.0487}$ & $-\underset{* \star *}{-0.2044}$ & -0.0110 & -0.2154 \\
\hline Tongzhou & $-\underset{\star \star \star \star}{0.4654}$ & $\underset{* * *}{-0.4539}$ & $\underset{* * *}{0.1037}$ & $\underset{* * \star}{-0.4539}$ & $\underset{* \star}{-0.0299}$ & -0.4838 \\
\hline Shijingshan & $-\underset{\star \star \star \star}{0.1311}$ & $-\underset{\star \star \star \star}{0.1161}$ & $\underset{\star \star \star}{-0.0051}$ & $-\underset{\star * \star}{0.1163}$ & $-\underset{\star \star \star *}{0.0516}$ & $-\underset{* * *}{-0.1678}$ \\
\hline
\end{tabular}

Note: ${ }^{\star} \mathrm{P}<0.1 ;{ }^{* *} \mathrm{P}<0.05 ;{ }^{* *} \mathrm{P}<0.01$. 